\title{
Review \\ The Diverse Roles of $\gamma \delta$ T Cells in Cancer: From Rapid Immunity to Aggressive Lymphoma
}

\author{
Susann Schönefeldt ${ }^{1}$, Tamara Wais ${ }^{1}$, Marco Herling ${ }^{2}$, Satu Mustjoki ${ }^{3,4,5}{ }^{(D}$, Vasileios Bekiaris ${ }^{6}$, \\ Richard Moriggl ${ }^{1}(\mathbb{D})$ and Heidi A. Neubauer ${ }^{1, *(D)}$
}

1 Institute of Animal Breeding and Genetics, University of Veterinary Medicine Vienna, 1210 Vienna, Austria; susann.schoenefeldt@vetmeduni.ac.at (S.S.); tamara.wais@meduniwien.ac.at (T.W.); richard.moriggl@vetmeduni.ac.at (R.M.)

2 Department of Hematology, Cellular Therapy and Hemostaseology, University of Leipzig, 04103 Leipzig, Germany; marco.herling@medizin.uni-leipzig.de

3 Hematology Research Unit Helsinki, Helsinki University Hospital Comprehensive Cancer Center, 00290 Helsinki, Finland; satu.mustjoki@helsinki.fi

4 iCAN Digital Precision Cancer Medicine Flagship, 00014 Helsinki, Finland

5 Translational Immunology Research Program and Department of Clinical Chemistry and Hematology, University of Helsinki, 00014 Helsinki, Finland

6 Department of Health Technology, Technical University of Denmark, 2800 Kongens Lyngby, Denmark; vasbek@dtu.dk

* Correspondence: heidi.neubauer@vetmeduni.ac.at; Tel.: +43-1-25-077-5641

Citation: Schönefeldt, S.; Wais, T.; Herling, M.; Mustjoki, S.; Bekiaris, V.; Moriggl, R.; Neubauer, H.A. The Diverse Roles of $\gamma \delta$ T Cells in Cancer: From Rapid Immunity to Aggressive Lymphoma. Cancers 2021, 13, 6212. https://doi.org/10.3390/

cancers 13246212

Academic Editor: Alberto Zamò

Received: 1 October 2021

Accepted: 3 December 2021

Published: 9 December 2021

Publisher's Note: MDPI stays neutral with regard to jurisdictional claims in published maps and institutional affiliations.

Copyright: (c) 2021 by the authors. Licensee MDPI, Basel, Switzerland. This article is an open access article distributed under the terms and conditions of the Creative Commons Attribution (CC BY) license (https:/ / creativecommons.org/licenses/by/ $4.0 /)$.
Simple Summary: $\gamma \delta$ T cells play important roles in cancer immunity. Their rapid activation and cytotoxic nature make them promising candidates for use in cell-based immunotherapies; however, under certain conditions, they can induce pro-tumour functions. Furthermore, upon transformation, $\gamma \delta \mathrm{T}$ cells can develop into aggressive lymphomas with a poor prognosis and no curative therapeutic options. Here, we provide a comprehensive summary of our current knowledge on the complex roles of $\gamma \delta \mathrm{T}$ cells in cancer. We discuss their anti- and pro-tumour functions in both solid and blood cancers, highlighting the key subsets involved and their potential utility in anti-cancer immunotherapy. We also discuss the mechanisms of $\gamma \delta$ T-cell transformation, summarising the resulting $\gamma \delta$ T-cell leukaemia/lymphoma entities and their genetic and molecular profiles, as well as current and future treatment strategies.

Abstract: $\gamma \delta \mathrm{T}$ cells are unique players in shaping immune responses, lying at the intersection between innate and adaptive immunity. Unlike conventional $\alpha \beta$ T cells, $\gamma \delta$ T cells largely populate non-lymphoid peripheral tissues, demonstrating tissue specificity, and they respond to ligands in an MHC-independent manner. $\gamma \delta \mathrm{T}$ cells display rapid activation and effector functions, with a capacity for cytotoxic anti-tumour responses and production of inflammatory cytokines such as IFN- $\gamma$ or IL-17. Their rapid cytotoxic nature makes them attractive cells for use in anti-cancer immunotherapies. However, upon transformation, $\gamma \delta \mathrm{T}$ cells can give rise to highly aggressive lymphomas. These rare malignancies often display poor patient survival, and no curative therapies exist. In this review, we discuss the diverse roles of $\gamma \delta$ T cells in immune surveillance and response, with a particular focus on cancer immunity. We summarise the intriguing dichotomy between pro- and anti-tumour functions of $\gamma \delta$ T cells in solid and haematological cancers, highlighting the key subsets involved. Finally, we discuss potential drivers of $\gamma \delta$ T-cell transformation, summarising the main $\gamma \delta$ T-cell lymphoma/leukaemia entities, their clinical features, recent advances in mapping their molecular and genomic landscapes, current treatment strategies and potential future targeting options.

Keywords: cancer immunity; $\gamma \delta \mathrm{T}$ cells; $\gamma \delta \mathrm{T}$-cell lymphoma; immunotherapy; targeted therapy; $\gamma \delta$ T-cell transformation 


\section{Introduction}

$\gamma \delta \mathrm{T}$ cells are a unique set of 'unconventional' T cells that reside at the interface between innate and adaptive immunity [1]. The primary functions of $\gamma \delta \mathrm{T}$ cells are to provide rapid responses to ensure tissue integrity, maintain immune and tissue homeostasis [2,3], sense and fight against cancer and uphold critical host defence and barrier function towards foreign antigens [4-6]. These roles are facilitated by their unique tissue distribution; whereas conventional $\alpha \beta$ T cells mainly reside in lymphoid organs, $\gamma \delta$ T cells preferentially home to and reside in mucosal and epithelial tissues of peripheral organs, which are not usually under surveillance by $\alpha \beta$ T cells in the absence of a specific activation signal. Rapid $\gamma \delta$ T-cell activation occurs via direct detection of ligands by the T-cell receptor (TCR) or other activating receptors in a major histocompatibility complex (MHC)-independent manner, which again sets them apart from $\alpha \beta$ T cells [7].

With respect to their TCR assembly, unlike $\alpha \beta$ T cells that have randomly-paired receptor chains, the $\gamma$ and $\delta$ chain pairing is restricted to only a few common combinations, resulting in distinct $\gamma \delta$ T-cell subsets [8]. The genes for the $\gamma$ TCR (TCRG) are located on chromosome 13 in mice and chromosome 7 in humans, and genes for the $\delta$ TCR (TCRD) are found on chromosome 14 in both mice and humans [9]. Between mouse and human, there are species-specific variations in the chain rearrangements [10]. As such, the consensus regarding $\gamma \delta$ T-cell nomenclature is to define human $\gamma \delta$ T cells by their $\delta$ chain segment and mouse $\gamma \delta \mathrm{T}$ cells by their $\gamma$ chain segment. In mice, the most commonly found $\gamma \delta$ T cell subtypes include $\mathrm{V} \gamma 1, \mathrm{~V} \gamma 4, \mathrm{~V} \gamma 5, \mathrm{~V} \gamma 6$ and $\mathrm{V} \gamma 7$ (nomenclature by Heilig and Tonegawa) [11]. In humans, the main $\gamma \delta \mathrm{T}$-cell subsets can be divided into V $\delta 1, \mathrm{~V} \delta 2$ and the very minor V83-expressing subsets (nomenclature by Lefranc and Rabbitts) [12] (Figure 1). Importantly, specific $\mathrm{V} \gamma$ and $\mathrm{V} \delta$ chain combinations allow for the recognition of different types of ligands, facilitating the distinct $\gamma \delta \mathrm{T}$-cell functions needed in different resident tissues [7]. Interestingly, the $V \delta 2$ chain preferentially pairs with the $V \gamma 9$ chain, whereas the $V \delta 1$ and $V \delta 3$ chains do not have such $V \gamma$ chain preferences. In contrast to the other subtypes, the $\mathrm{V} \gamma 9 \mathrm{~V} \delta 2$ subset is the predominant $\gamma \delta \mathrm{T}$-cell subtype in the peripheral blood (making up $\approx 50-90 \%$ of $\gamma \delta \mathrm{T}$ cells) and is, to date, the most investigated for their role in health and disease, especially in cancer and immunotherapy [13-17].

Functionally, $\gamma \delta$ T cells can be rapidly activated by specific receptor-ligand interactions [7], upon which they possess the capacity for clonal expansion and provide a major source of cytokine and chemokine production [18-21]. This facilitates their abilities to exert direct or indirect immune responses by functioning as professional antigen presenting cells (APCs) [22,23], providing T- and B-cell helper functions [24] or directly killing compromised cells [25-27]. Importantly, $\gamma \delta \mathrm{T}$ cells can rapidly respond to specific ligand types that are not recognised by other immune cells, where stress signal recognition by $\gamma \delta \mathrm{T}$ cells as one example in particular is critical for the immune detection of many cancers [28,29]. Consequently, $\gamma \delta$ T cells provide an important, active link between the adaptive and innate arms of the immune system, making them key effector cells in cancer immunity [8].

In this review, we summarise the complex roles of $\gamma \delta \mathrm{T}$ cells in cancer, from their clear anti-tumour activities in both solid and haematological cancers, to their intriguing, dichotomous roles in maintaining and promoting tumour growth. Finally, we also discuss the aggressive lymphomas that can arise when $\gamma \delta \mathrm{T}$ cells themselves become malignant, highlighting the key genetic features of these cancers and summarising the latest treatment directions. 


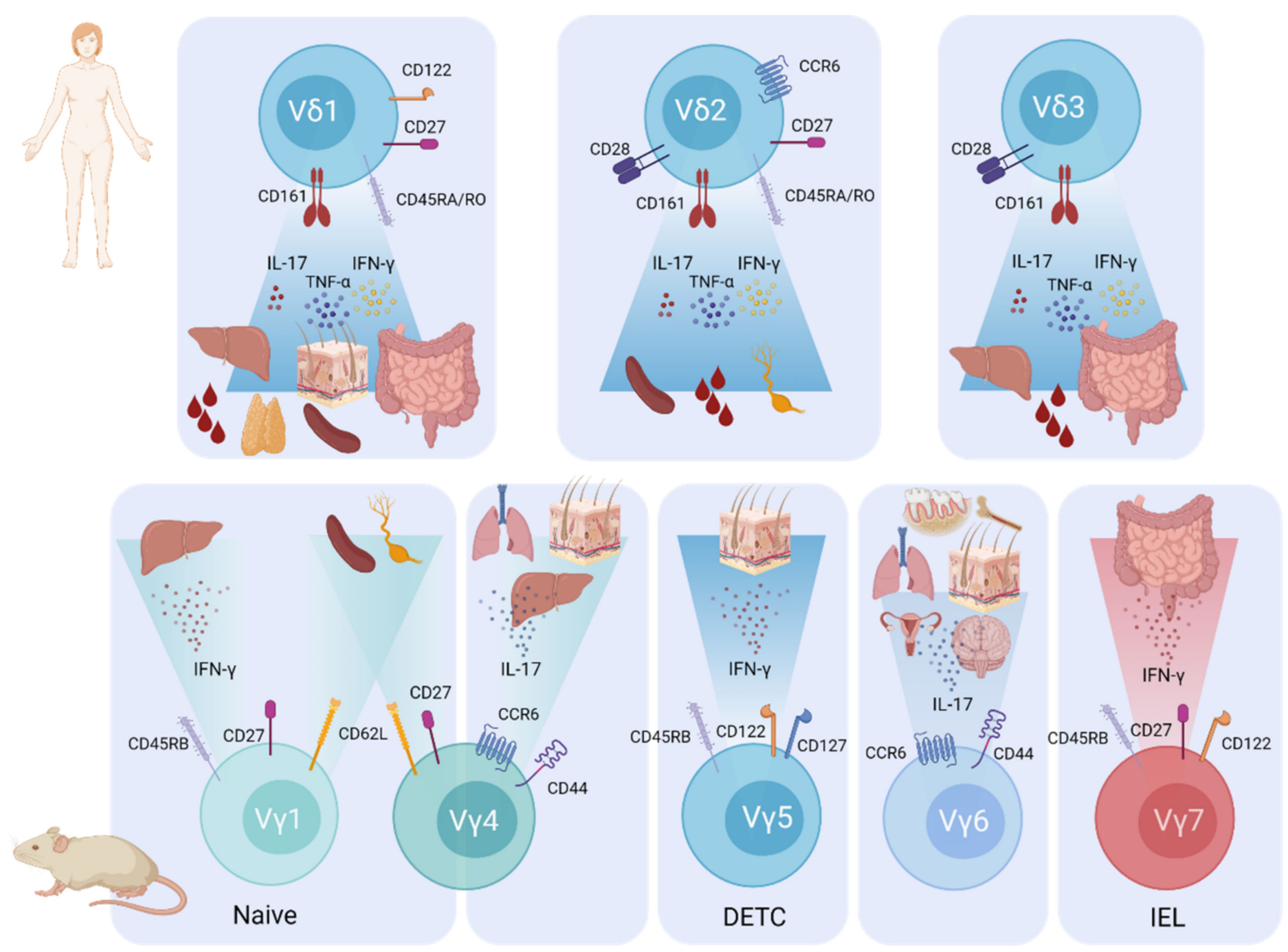

Figure 1. Attributes of $\gamma \delta$ T-cell subsets most commonly found in humans or mice. The main human $\gamma \delta$ T-cell subsets, $\mathrm{V} \delta 1, \mathrm{~V} \delta 2$ and V $\delta 3$ (top), and the main murine $\gamma \delta \mathrm{T}$-cell subsets, $\mathrm{V} \gamma 1, \mathrm{~V} \gamma 4, \mathrm{~V} \gamma 5, \mathrm{~V} \gamma 6$ and $\mathrm{V} \gamma 7$ (bottom), are shown. Key surface molecules, dominant cytokines and main tissue distributions are depicted [10]. Top: Human $\gamma \delta \mathrm{T}$ cells can be positive for CD161 (IL-17-producers) [30], CCR6, CD28, CD27, CD122 and CD45RA/RO surface markers, depending on the immunological and tumour microenvironmental context. CD45RA and CD27 surface expression can define specific subtypes: naïve $\left(\mathrm{CD}_{4} 5 \mathrm{RA}^{+} \mathrm{CD} 27^{+}\right)$, memory $\left(\mathrm{CD} 45 \mathrm{RA}^{-} \mathrm{CD}^{+} 7^{+}\right.$), activated effector memory $\left(\mathrm{CD} 45 \mathrm{RA}^{-} \mathrm{CD}^{-} 7^{-}\right)$and terminally differentiated $\left(\mathrm{CD}_{4} 5 \mathrm{RA}^{+} \mathrm{CD}^{-} 7^{-}\right.$) cells $[31,32]$. Human $\gamma \delta$ T cells are predominantly IFN- $\gamma$ - and TNF- $\alpha$-producing effectors; however, all subsets can produce IL-17 under certain conditions. Bottom: Mouse $\mathrm{V} \gamma 1^{+} \mathrm{T}$ cells are largely IFN- $\gamma$-producing and have CD45RB and CD27 surface expression. $\mathrm{V} \gamma 4^{+} \mathrm{T}$ cells are predominantly IL-17-producing and express CCR6 and $\mathrm{CD} 44$. Both $\mathrm{V} \gamma 1^{+}$and $\mathrm{V} \gamma 4^{+} \mathrm{T}$ cells can also home to secondary lymphoid tissues (expressing CD62L). IFN- $\gamma$-producing $\mathrm{V} \gamma 5^{+}$dendritic epidermal T cells (DETCs) express CD45RB, CD122 and CD127. ${\mathrm{V} \gamma 6^{+}}^{\mathrm{T}}$ cells are primarily IL-17-producing and are positive for CD44 and CCR6. $\mathrm{V} \gamma 7^{+}$intraepithelial lymphocytes (IELs) expressing CD45RB, CD27 and CD122 primarily secrete IFN- $\gamma$. The nomenclature used for T-cell receptor genes is based on the Heilig and Tonegawa system for mouse and the Lefranc and Rabbitts system for human $\gamma \delta$ T cells [11,12]. CCR, CC chemokine receptor; CD, cluster of differentiation; IFN- $\gamma$, interferon- $\gamma$; IL, interleukin; TNF- $\alpha$, tumour necrosis factor- $\alpha$.

\section{Functional $\gamma \delta$ T-Cell Subsets in Mice and Humans}

The faceted roles of $\gamma \delta$ T cells in cancer are shaped by multiple regulators that determine whether they take on a pro- or anti-tumour role, very much depending on their initial effector type programming [33-35], the tumour microenvironmental context [36-38], encounters with other tumour-associated immune cells $[39,40]$ and the tumour entities themselves $[41,42]$. Indeed, $\gamma \delta \mathrm{T}$ cells are critical cells in cancer as well as in general immunity [2,43]; they are the first T cells to develop [44], leave the embryonic thymus and home to their target tissues [45]. Here, they are found throughout the entirety of life as deeply embedded into the cellular organisational structure $[46,47]$.

Generally, murine $\gamma \delta$ T cells can be functionally subtyped into RAR-related orphan receptor gamma (ROR $\gamma \mathrm{t}$ )-programmed interleukin-17A (IL-17)-producing $\gamma \delta \mathrm{T}(\gamma \delta \mathrm{T} 17)$ cells $[10,43]$ and T-box 21 (T-bet)-programmed interferon- $\gamma(\mathrm{IFN}-\gamma)$-producing $\gamma \delta \mathrm{T}(\gamma \delta \mathrm{T} 1)$ cells [48]. There is a clear association between TCR V $\gamma$ chain usage and effector subtype: 
murine $\mathrm{V} \gamma 1^{+}, \mathrm{V} \gamma 5^{+}$and $\mathrm{V} \gamma 7^{+} \gamma \delta \mathrm{T}$ cells are biased towards IFN- $\gamma$ production, whereas $\mathrm{V} \gamma 4^{+}$and $\mathrm{V} \gamma 6^{+} \gamma \delta \mathrm{T}$ cells largely produce IL-17 (Figure 1). Three separate factors have been proposed to account for fate decisions of murine $\gamma \delta \mathrm{T} 17$ or $\gamma \delta \mathrm{T} 1$ effector lineage development in immature thymocytes: (i) TCR signal strength [49], (ii) Notch signalling [50] and (iii) cytokine encounter during the double negative DN3 development stage $[45,50]$. Notably, while strong $\gamma \delta$ TCR signalling can prohibit $\gamma \delta \mathrm{T} 17$ in favour of $\gamma \delta \mathrm{T} 1$ lineage commitment, additional Notch signalling and the addition of certain cytokines can skew the functional phenotype towards the $\gamma \delta T 17$ lineage [49]. Specifically, Sumaria et al., found in mice that while Notch signalling alone was not able to induce the $\gamma \delta \mathrm{T} 17$ lineage, it was still a requirement, and only in combination with $\gamma \delta$ T17-associated cytokines (IL-1 $\beta$, IL-21 and IL-23) was it able to induce the transcriptional network for IL-17 production [49]. As a very recent concept, Lopes et al. found that TCR signal strength also determines the metabolic programming of $\gamma \delta$ T cells during thymic development in mice, coinciding with their effector lineage commitment [34]. Specifically, the authors showed that $\gamma \delta \mathrm{T} 17-$ programmed cells solely utilise oxidative phosphorylation, whereas strong TCR signalling and initiation of the $\gamma \delta \mathrm{T} 1$ program induces a switch to glycolysis [34]. These subset metabolic requirements could provide interesting new implications for improving $\gamma \delta \mathrm{T}-$ cell-based immune therapy. We have also recently shown that $\gamma \delta$ T-cell effector subtypes are regulated differentially by the two STAT5 proteins, STAT5A/B, using specific gainor loss-of-function transgenic mouse models [33]. Herein, dominant STAT5A signalling promoted ROR $\gamma \mathrm{t}$ expression, whereas STAT5B signalling favoured T-bet upregulation, resulting in lineage skewing towards either $\gamma \delta$ T17 by STAT5A or $\gamma \delta$ T1 by STAT5B, revealing non-redundant roles of STAT5 homologs in fine-tuning $\gamma \delta$ T-cell lineage commitment [33].

In contrast to murine $\gamma \delta$ T cells, there is no association between TCR V $\delta$ chain usage and the functional subtype of human $\gamma \delta \mathrm{T}$ cells; V $\delta 1, \mathrm{~V} \delta 2$ and $\mathrm{V} \delta 3 \gamma \delta \mathrm{T}$ cells are present most commonly as the IFN- $\gamma$-producing $\gamma \delta \mathrm{T} 1$ subtype $[32,51]$, while no dedicated human $\gamma \delta \mathrm{T} 17$ subset has been identified. There is, however, compelling evidence that under certain circumstances, all human $\gamma \delta$ T cells can produce IL-17 [52-55]. For example, it was shown that a subpopulation of $\mathrm{CD} 28^{+} \mathrm{V} \gamma 9 \mathrm{~V} \delta 2$ cells produce IL-17, are positive for CD27 and CCR6 and express type-3 signature genes such as RORC and IL23R [56]. Notably, the recent identification of $\gamma \delta \mathrm{T} 17 \mathrm{~V} \delta 2$ cells in human embryonic thymus also suggests a potential pre-programing mechanism similar to mice [57].

Plasticity, or polarisation, is another important aspect of $\gamma \delta$ T-cell physiology [58], resulting in effector function switching even after thymic selection and initial phenotypic programming [33]. Interestingly, polarisation and activation patterns usually occur in an inflammatory or cancer-immunity context [59-61]. These processes are often triggered by cytokine stimulation and coupled with TCR stimulation, leading to changes in transcription factor expression and resulting in altered expression of effector molecules and cytokines. Indeed, the right stimulus on a resting (non-activated) $\gamma \delta \mathrm{T}$ cell can promote switching between the effector subtypes. Aside from the two main subtypes, $\gamma \delta \mathrm{T} 1$ and $\gamma \delta \mathrm{T} 17$, other putative populations have been reported (e.g., $\gamma \delta \mathrm{T}$ follicular helper (Tfh)-like cells [62] and forkhead box P3 (FOXP3) ${ }^{+} \gamma \delta$ T regulatory (Treg)-like cells [63]). In the cancer context, the main extrathymic regulator of $\gamma \delta$ T-cell plasticity is the tumour microenvironment (TME) [38]. As discussed further below, the TME provides an abundance of cytokines as well as hypoxic conditions (in the case of many solid cancers) [42,64-67], contributing to the polarisation of $\gamma \delta$ T cells into different effector subtypes and thereby promoting either anti- or pro-tumour functions $[64,65,68]$.

The dichotomy of $\gamma \delta$ T cells in cancer immunity lies in the fact that, in general, the $\gamma \delta \mathrm{T} 1$ effector subtype is associated with anti-tumour roles, whereas $\gamma \delta \mathrm{T} 17$ cells have been extensively shown in murine studies to possess pro-tumour functions. In humans, it has been until recently very difficult to study this subtype due to their rarity, tissue-resident nature and lack of protocols for their in vitro expansion. However, recent advancements in this area have facilitated the study of $\gamma \delta \mathrm{T} 17$ cells and their pro-tumour functions in 
humans [43]. Herein, we focus mainly on the roles of human $\gamma \delta$ T-cell subsets in cancer immunity, where possible.

\section{Anti-Tumour Functions of $\gamma \delta$ T Cells}

$\gamma \delta$ T-cell anti-tumour responses can be categorised into: cellular fitness and stress ligand sensing, death receptor engagement, antibody dependent cytotoxicity (ADCC) and execution of T helper functions (Figure 2). These functions of $\gamma \delta \mathrm{T}$ cells are facilitated by their rapid cytotoxic activity upon stimulation with specific ligands of their TCR in conjunction with other activating receptors, including Toll-like receptor (TLR) [69], CD16 (Fc $\gamma$ RIIIA) [70], CD226 (DNAX accessory molecule-1 [DNAM-1]) [71], CD28 [72], natural killer group 2 member D (NKG2D) [73,74] and natural killer receptors [75] (NKRs; NKp30 [76], NKp44 [77] and NKp46 [73,78]). Activating ligands include non-peptide substances such as phosphoantigens (PAgs) [79], aminobisphosphonates [80] and alkylamines $[81,82]$ as metabolites of the mevalonate pathway upregulated in cancer cells [83], as well as MHC class I polypeptide-related sequence A/B (MICA/MICB) [75,84], heat shock proteins [85], butyrophilins/butyrophilin-like (BTN/BTNL) molecules [20,21] and members of unique long 16 (UL-16)-binding proteins (ULBP/RAET1) [86,87].

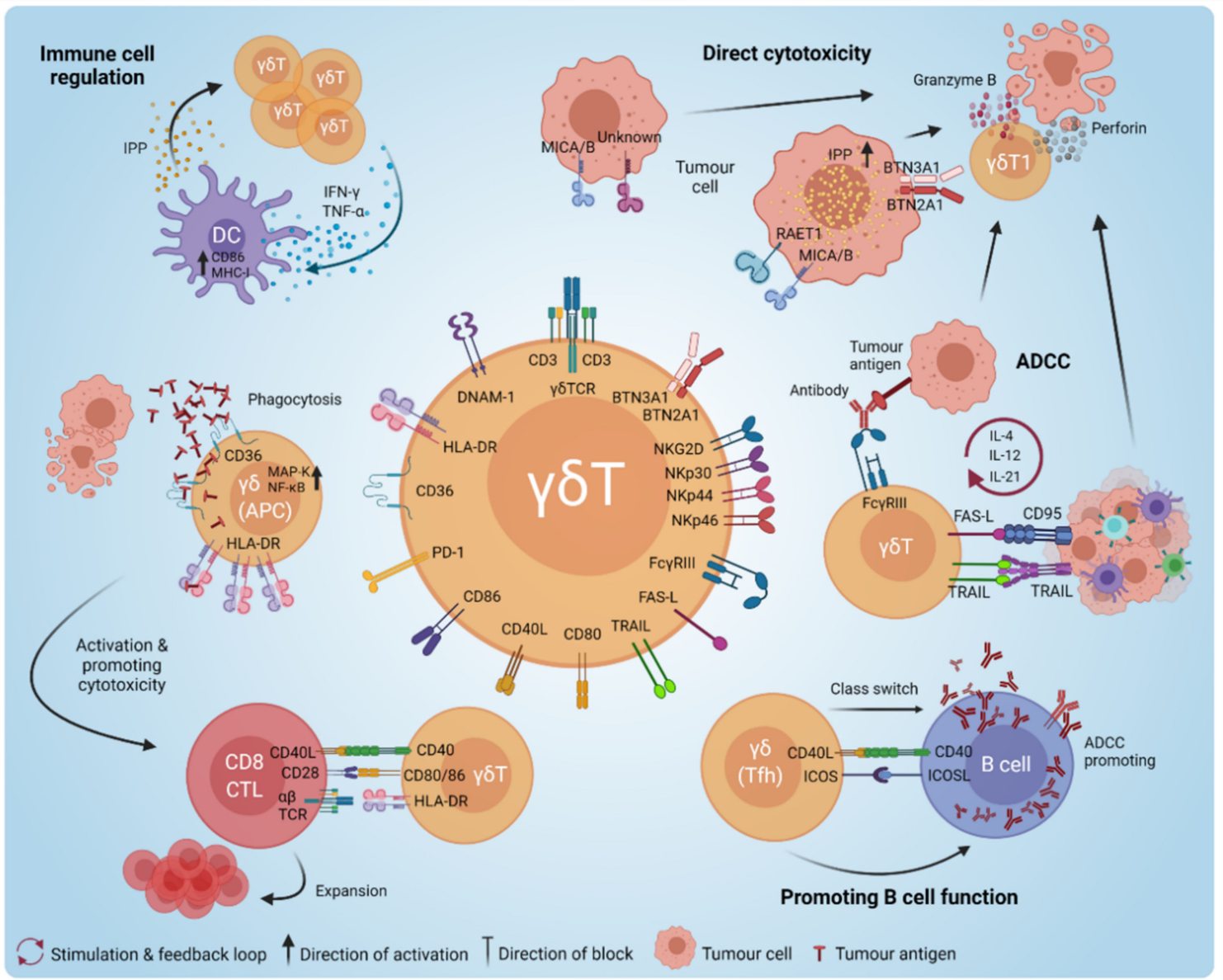

Figure 2. Anti-tumour functions of $\gamma \delta$ T cells. Direct cytotoxicity is induced by detection of intracellular stress signalling in tumour cells (i.e., RAET1, MICA/B ligands, IPP production), engagement of the $\gamma \delta$ TCR and death receptors (i.e., TRAIL, FAS) and granzyme B/perforin release. Antibody-dependent cellular cytotoxicity (ADCC) via the Fc $\gamma$ RIIIA receptor can also induce target cell death. $\gamma \delta \mathrm{T}$ cells can promote anti-tumour functions indirectly through immune cell regulation, via promoting B-cell function and class switch to antibody production; interaction/promotion of dendritic cell (DC) activity; acting as an antigen presenting cell (APC) via scavenger receptor activity (i.e., CD36) and promoting CD8 ${ }^{+}$cytotoxic $\mathrm{T}$ lymphocyte (CTL) function via CD40, CD80 and HLA-DR engagement. IPP, isopentenyl pyrophosphate. 
Interestingly, cellular stress can be perceived differently by the two main human $\gamma \delta \mathrm{T}$ cell subtypes. While specific V $\delta 1$ TCR ligands remain elusive, these cells are highly efficient in detecting cellular stress signals (e.g., stress-induced ligands or glycolipids $[85,88]$ and glycans $[89,90])$. The activation of $\mathrm{V} \delta 1^{+}$cells by TCR engagement combined with cytokine stimulation (i.e., IL-2 or IL-15) upregulates NKRs, correlating with CD56 expression and potent anti-tumour cytotoxicity [76,91]. Both V $\delta 1$ and V $82 \mathrm{~T}$ cells can detect MICA/B and ULBP ligands on cancer cells via interaction with their NKG2D receptor [92,93], facilitating their activation $[74,75]$ and leading to the release of perforin and granzyme B $[93,94]$. Interestingly, the crystallisation of the V $\delta 1$ TCR revealed a direct interaction with MICA, although this interaction is of a significantly lower affinity than that of the NKG2D-MICA interaction [84]. On the other hand, it is well established that V $\delta 2^{+} \mathrm{T}$ cells can respond strongly to PAgs such as isopentenyl pyrophosphate (IPP), which is a metabolite of the mevalonate or microbial deoxyxylulose phosphate pathway $[7,95,96]$. Cancer cells often have a dysregulated mevalonate pathway, resulting in intracellular accumulation of IPP, which can be sensed by $\mathrm{V} \gamma 9 \mathrm{~V} \delta 2 \mathrm{~T}$ cells, leading to their activation and anti-tumour functions. This mechanism involves IPP binding to the intracellular domain of the butyrophilin molecule BTN3A1 expressed on cancer cells, which interacts with BTN2A1 to bind and activate the TCR on V $\gamma 9 \mathrm{~V} \delta 2$ cells $[97,98]$. IPP can also be secreted from cancer cells and APCs into the extracellular environment to activate $\mathrm{V} \gamma 9 \mathrm{~V} \delta 2 \mathrm{~T}$ cells, and this mechanism was shown to involve the ATP-binding cassette transporter A1 (ABCA1) in cooperation with apolipoprotein A-I (apoA-I) and BTN3A1 [18]. Notably, $\gamma \delta$ T-cell ligand interactions can vary between mice and humans. For example, PAgs are not recognised by murine $\gamma \delta \mathrm{T}$ cells due to the lack of an equivalent $\mathrm{V} \gamma 9 \mathrm{~V} \delta 2$ subset $[10,29,96,99]$. This is important to consider when using models to understand $\gamma \delta \mathrm{T}$-cell biology as well as developing $\gamma \delta$ T-cell-based cancer immunotherapy. This is currently being addressed by the use of humanised murine models (e.g., that express human receptor molecules on $\gamma \delta$ T cells) $[21,28,29,100,101]$.

$\gamma \delta \mathrm{T}$ cells can also mediate direct cytotoxicity via the engagement of death receptor pathways, acting upon tumour necrosis factor-related apoptosis-inducing ligand (TRAIL) and FAS ligand (FASL) [102,103] (Figure 2). Supporting this, Tawfik et al., demonstrated that reduced TRAIL-R4 expression in cancer cells rendered them less sensitive to V $\delta 1$ - and V 82 -mediated cytotoxicity in an ERK/COX2-dependent manner [27].

Another $\gamma \delta$ T-cell mechanism to exert anti-tumour function is through antibodydependent cellular cytotoxicity (ADCC). Here, a tumour antigen-specific antibody binds to the tumour cell, allowing the FC segment to be bound by the Fc $\gamma$ RIIIA receptor on $\gamma \delta \mathrm{T}$ cells, inducing $\gamma \delta \mathrm{T}$-cell activation and killing of the tumour cell. This mechanism can be exploited to target and kill tumour cells using specific targeting antibodies (e.g., anti-CD20), which were shown to enhance the cytotoxicity of stimulated/expanded $V \gamma 9 \mathrm{~V} \delta 2$ cells [104]. $\gamma \delta \mathrm{T}$ cells can also further indirectly promote ADCC by acting as regulators/helpers of the peripheral B-cell repertoire [24], thereby supporting humoral immunity against tumour cells. In a murine model, it was shown that in the absence of $\mathrm{CD}^{+} \alpha \beta$ T-cell populations, $\gamma \delta \mathrm{T}$ cells may support B germinal centre formation [105]. A more recent study reported that $\gamma \delta \mathrm{T}$ cells could shape B-cell maturation by directly affecting the transitional stages of marginal zone B cells, which was dependent on the $\mathrm{V} \gamma \mathrm{TCR}$ chain expressed [106]. For instance, a loss of $\mathrm{V} \gamma 4$ and $\mathrm{V} \gamma 6 \mathrm{~T}$ cells led to a stark loss of peripheral B-cell populations [106]. Interestingly, a subset of human $V \gamma 9 \mathrm{~V} \delta 2 \mathrm{~T}$ cells isolated from peripheral blood were found to express C-X-C chemokine receptor type 5 (CXCR5) and could, upon stimulation, express the costimulatory molecules ICOS and CD40L, inducing the production of B helper cytokines such as IL-2, IL-4, IL-10 and IL-21 to benefit B-cell functions $[107,108]$. Similarly, V $83^{+} \mathrm{T}$ cells were also shown to upregulate CD40, CD86 and HLA-DR, leading to the production of IgM by B cells [109]. Taken together, these studies demonstrate that $\gamma \delta \mathrm{T}$ cells can provide B-cell helper function in support of antibody production and class switching, which supports ADCC anti-tumour functions (Figure 2). 
$\gamma \delta \mathrm{T}$ cells can also act as excellent T helper cells to support other immune cell types involved in anti-cancer immunity. For one, they have the capacity to function as professional APCs [110], upregulating the scavenger receptor CD36 to facilitate the uptake of tumour antigens mediated via mitogen-activated protein kinase (MAPK) and NF- $\mathrm{B}$ pathway signalling [111,112]. In turn, this upregulates the co-stimulatory molecules CD40, CD80 and CD86, as well as the MHC class II molecule HLA-DR on $\gamma \delta$ T cells to facilitate the activation of cytotoxic CD8 ${ }^{+}$T cells $[113,114]$. Another aspect of their helper function is the interaction between $\gamma \delta$ T cells and dendritic cells (DC). This is a reciprocal relationship, whereby mature DCs can induce the activation and proliferation of $\gamma \delta$ T cells $[115,116]$ via the release of IPP [18], and $\gamma \delta$ T cells can in turn promote the maturation of DCs [117] via secretion of IFN- $\gamma$ and TNF- $\alpha$ to increase DC expression of CD86 and MHC-I molecules [118,119] (Figure 2). It was also found that $\mathrm{V} \delta 3^{+} \mathrm{T}$ cells can be stimulated to release certain Th1 (IFN- $\gamma$, TNF- $\alpha$ ), Th2 (IL-4) and Th17 (IL-17) cytokines to induce DC maturation [120].

\section{1. $\gamma \delta$ T Cells in Solid Cancers}

In human solid cancers, $\gamma \delta$ tumour-infiltrating lymphocytes (TILs) have been proposed by many studies to be relevant prognostic factors; however, there appear to be differences in their anti-tumour functions across different solid cancer types. Notably, their tumour infiltration and cytolytic activity have been linked with a beneficial role for patient outcome in gastric cancer [121,122], hepatocellular carcinoma [68], ovarian cancer [123], colorectal cancer [124,125], renal cell carcinoma [126,127], glioblastoma [128] and triplenegative breast cancer [129-131]. On the other hand, they were also reported to have a negative impact on prognosis in ovarian cancer [37] and oral cancer [42], and conflicting studies also found them to positively correlate with pathogenesis in colon cancer [132] and breast cancer $[133,134]$. These conflicting findings appear to be mediated by the different $\gamma \delta$ T-cell effector subtypes: anti-tumour functions generally involve $\gamma \delta \mathrm{T} 1$ cells, and protumour outcomes are linked with $\gamma \delta \mathrm{T} 17$ cells [135]. The pro-tumour functions of $\gamma \delta \mathrm{T} 17$ cells are discussed later in more detail.

Foord et al. demonstrated that epithelial ovarian cancer-derived $\gamma \delta \mathrm{T}$ cells, when stimulated, produced large amounts of IFN- $\gamma$ but not IL-17 or IL-10 [123]. Furthermore, they showed that these $\gamma \delta$ T cells effectively exercised cytolytic activities against ovarian cancer cells to a greater extent than patient-derived CD8 ${ }^{+} \mathrm{T}$ cells, and that patients who had more responsive $\gamma \delta \mathrm{T} 1$ cells upon stimulation had smaller residual tumour burden and increased overall survival (OS), whereas the IFN- $\gamma$ secretion capacity of $\alpha \beta$ T cells was found to have no effect on patient survival [123]. In line with this, a recent investigation of human breast cancer patients revealed that IFN- $\gamma$-producing V $\delta 1^{+}$TILs displayed cytotoxic capacity towards breast cancer cell lines and positively correlated with increased patient progression free survival (PFS) and OS [131]. In these patients, $\alpha \beta$ TCR $^{+}$TILs were also correlated with increased PFS and, interestingly, a positive and significant correlation of tumour-infiltrating TCR $\alpha^{+}$cells with $\mathrm{V} \delta 1^{+}$cells was reported, where the authors propose that maximal patient benefit may arise from the synergistic effect of innate-like $\gamma \delta$ and adaptive $\alpha \beta$ TILs [131]. In squamous cell cancer patients, Lo Presti et al. found that early stage tumours had a predominance of $\gamma \delta \mathrm{T} 1 \mathrm{TILs}$, and that a higher frequency of $\gamma \delta \mathrm{T} 1$ cells correlated with a favourable patient outcome shown by an absence of relapse, lymph node invasion and mortality at follow-up [136]. Notably, in the same study, it was found that late-stage cancer patients switched to a dominance of $\gamma \delta \mathrm{T} 17$ TILs, where a higher frequency of $\gamma \delta \mathrm{T} 17$ cells was linked to higher relapse rates, lymph node metastasis and higher mortality rates, emphasising the functional dichotomy between these two effector subtypes in solid cancer immunity [136].

\section{2. $\gamma \delta$ T Cells in Haematological Malignancies}

Interestingly, where the role of $\gamma \delta$ T cells in solid tumour immunity can be conflicting, blood cancers in general appear to be more susceptible to $\gamma \delta$ T-cell-mediated anti-tumour responses than solid tumours [137-139]. The cytotoxic response of $\gamma \delta \mathrm{T}$ cells against 
haematopoietic cancers in vitro has been demonstrated by numerous studies using cell lines or primary patient samples of acute myeloid leukaemia (AML) [25,140-142], chronic myeloid leukaemia (CML) [143], T-cell acute lymphoblastic leukaemia (T-ALL) [76,142], multiple myeloma [95,144,145], chronic lymphocytic leukaemia (CLL) [76,146], B-ALL [76,142] or other non-Hodgkin B-cell lymphomas $[142,145,147]$. $\gamma \delta$ T cells were also shown to contribute to the suppression of spontaneously developing B-cell lymphomas in transgenic mice [148], and $\gamma \delta$ T cells adoptively transferred into an Epstein-Barr virus (EVB)-induced mouse model of B-cell lymphoma significantly reduced disease burden [149].

Notably, there appear to be differences in the efficacy of haematopoietic cancer cell killing by $\mathrm{V} \delta 1^{+}$versus $\mathrm{V} \delta 2^{+}$cells. A number of studies have demonstrated anti-tumour responses of $\mathrm{V} \gamma 9 \mathrm{~V} \delta 2^{+}$cells against leukaemia/lymphoma models; $\mathrm{V} \gamma 9 \mathrm{~V} \delta 2 \mathrm{~T}$ cells transplanted into an AML xenograft mouse model were found to localise in close proximity to engrafted leukaemic cells and significantly increase survival [141]. $\mathrm{V} \gamma 9 \mathrm{~V} \delta 2^{+}$cells were also shown to have anti-tumour activity against CML cells in vitro and in vivo; however, this required the pre-treatment of CML cells with zoledronate and the administration of zoledronate plus IL-2 to mice in order to stimulate PAg expression on the tumour cells and maintain $\mathrm{V} \gamma 9 \mathrm{~V} \delta 2 \mathrm{~T}$-cell activation [143]. Similarly, only around one-third of primary AML patient samples were found to be intrinsically sensitive to the anti-tumour capacity of $\mathrm{V} \gamma 9 \mathrm{~V} \delta 2^{+}$cells, which was increased to $50 \%$ upon pre-treatment of the AML cells with bisphosphonates, while $50 \%$ of samples remained resistant [150]. In a clinical study administering IL-2 and pamidronate to patients with relapsed/refractory non-Hodgkin lymphoma or multiple myeloma, significant in vivo activation/proliferation of $\mathrm{V} \gamma 9 \mathrm{~V} \delta 2 \mathrm{~T}$ cells was difficult to achieve and partial remission was only achieved in $33 \%$ of patients, yet those that responded to the treatment demonstrated significant in vivo proliferation of $\mathrm{V} \gamma 9 \mathrm{~V} \delta 2$ cells [137]. On the other hand, V $\delta 1 \mathrm{~T}$ cells have emerged as having a particular affinity for haematological cancer cell targeting. Increased circulating V $\delta 1^{+} \mathrm{T}$-cell numbers, associated with high IL-4 serum levels and high tumour cell expression of ULBPs, were correlated with stable disease in a 1-year follow-up in patients with low-grade non-Hodgkin B-cell lymphoma [151]. In murine xenograft models, adoptive transfer of human $\mathrm{V} \delta 1^{+} \mathrm{T}$ cells reduced tumour growth and dissemination in a CLL model [146], and reduced disease burden and increased survival in an AML model [25].

The anti-tumour roles of $\gamma \delta \mathrm{T}$ cells in haematological cancer are further exemplified in cases of allogenic haematopoietic stem cell transplantation (aHSCT) as a treatment for leukaemia/lymphoma patients. aHSCT of $\alpha \beta$ T-cell/CD19 ${ }^{+}$B-cell-depleted bone marrow is now an established therapeutic protocol [152-155], where $\gamma \delta \mathrm{T}$ cells constitute the major T-cell population during reconstitution in the early stages post-transplantation [156]. Strikingly, a long-term follow up of acute leukaemia (ALL and AML) patients who underwent aHSCT revealed that patients who recovered with normal/low $\gamma \delta$ T-cell levels had a 6.7 times greater risk of death, primarily from recurrent disease, than those who had increased $\gamma \delta$ T cells [157]. The expanded $\gamma \delta$ T-cell subtype in $>90 \%$ of the surviving patients was predominately V $\delta 1$. Higher $\gamma \delta$ T-cell counts post-aHSCT were also correlated with improved OS in multiple myeloma [158] and AML patients [159], and were linked with a significantly reduced risk of relapse in AML patients [159]. Examination of circulating $\gamma \delta \mathrm{T}$ cells from acute leukaemia patients post-aHSCT revealed that cytotoxic $\left(\mathrm{CD} 107 \mathrm{a}^{+}\right) \mathrm{V} \delta 1^{+}$ cells were in higher proportions compared with their V $\delta 2^{+}$counterparts [156].

The recognition of leukaemia/lymphoma cells by $\mathrm{V} \gamma 9 \mathrm{~V} \delta 2 \mathrm{~T}$ cells is expectedly induced by the recognition of PAgs (often stimulated by treatment with aminobisphosphonates) and is mediated by TCR stimulation and granule exocytosis $[95,141,143,156]$. Susceptibility to $\mathrm{V} \gamma 9 \mathrm{~V} \delta 2 \mathrm{~T}$-cell-mediated killing has also been reported to require tumour cell expression of stress-induced molecules such as NKG2D ligand, ULBP1 [150,160], ligands for DNAM-1 [141] or the cell adhesion molecule ICAM-1 [95]. Interestingly, the picture is somewhat different for V 81 T-cell-mediated killing of blood cancer cells, where a strong cytotoxic response was shown to preferentially require the NKp30 receptor $[76,146]$ and associated tumour cell expression of the NKp30 ligand, B7-H6 [25], either indepen- 
dently of TCR signalling [76], or involving TCR activation [25,146]. Other studies have also shown an involvement of tumour cell ULBPs or ICAM-1 expression, or activating receptors NKG2D and DNAM-1 in mediating V $\delta 1$ cytotoxicity [144,151]. Since there is evidence that leukaemia/lymphoma cells can downregulate such ligand expression (e.g., ULBPs [151,160]), and that leukaemic stem cells do not express NKG2D ligands [161], allowing them to evade recognition by cytotoxic lymphocytes, understanding $\gamma \delta$ T-cell target recognition and killing mechanisms will be important to establish biomarkers of potential patient sensitivity or resistance to $\gamma \delta \mathrm{T}$-cell-mediated anti-tumour function. Indeed, through analysis of a panel of human blood cancer cell lines, a series of markers were previously reported to be associated with either sensitivity (ULBP1, TFR2 and IFITM1) or resistance (CLEC2D, NRP2, SELL, PKD2, KCNK12, ITGA6 and SLAMF1) to V $\gamma 9 \mathrm{~V} \delta 2$ T-cell-mediated cytotoxicity [142].

It is not entirely clear why haematopoietic cancer cells may be intrinsically more susceptible to $\gamma \delta$ T-cell recognition and killing compared with solid tumours. Factors such as increased activity of the mevalonate pathway (and thereby, increased expression of PAgs), higher expression of natural cytotoxicity receptor ligands or the inherent nature of various haematopoietic cells as professional APCs to recruit $\mathrm{T}$ lymphocytes have been proposed [139]. It could also be influenced by the lack of recruitment or induction of 'pro-tumour' $\gamma \delta \mathrm{T}$ cells, as discussed further below. Kunzmann and colleagues revealed in a clinical study that serum levels of vascular endothelial growth factor (VEGF) were higher in patients with renal cell carcinoma and melanoma compared with AML patients, which seemed to correlate with a lack of response to V $\gamma 9 \mathrm{~V} \delta 2 \mathrm{~T}$-cell anti-tumour activity upon zoledronic acid administration [138]. The pro-tumour functions of IL-17-producing $\gamma \delta \mathrm{T}$ cells have been linked to IL-17-induced VEGF production by tumour cells to stimulate angiogenesis [162], a mechanism only relevant to solid tumours. Finally, the TME, which is vastly different between solid and haematopoietic cancers, plays a large role in shaping the functions of $\gamma \delta$ T cells in tumour immunity.

\section{3. $\gamma \delta T$ Cells as Tools for Immunotherapies}

The direct recognition, rapid activation and cytotoxic capacity of $\gamma \delta \mathrm{T}$ cells towards cancer cells makes them very attractive tools for cancer immunotherapy, as recently extensively reviewed $[15,163,164]$. V $\delta 2^{+} \mathrm{T}$ cells exhibit pronounced inhibitory effects on tumourigenesis and tumour growth in a variety of malignancies and are a current hot topic in cancer immunotherapy efforts $[99,165,166]$. The advantage that human $V \gamma 9 \mathrm{~V} \delta 2$ $\mathrm{T}$ cells can be efficiently activated with specific cytokine and ligand stimuli (e.g., IL-2 plus aminobisphosphonates) in vitro allows for the required expansion of clinical grade autologous $\gamma \delta$ T-cell products. However, despite the demonstrated safety of administering expanded and activated $\mathrm{V} \gamma 9 \mathrm{~V} \delta 2 \mathrm{~T}$ cells to cancer patients, the clinical outcomes have only shown modest therapeutic efficacy thus far $[15,165]$. There is also great potential for the V $\delta 1$ subtype in cancer immunotherapy, on the one hand for their distinct ligand recognition but most importantly because they are less susceptible to T-cell exhaustion and activation-induced cell death (AICD) [167-169]. There have been recent advances to overcome the caveat of lacking clinical protocols to stimulate and expand V $\delta 1 \mathrm{~T}$ cells in vitro $[25,146]$, which will now pave the way for their use in cancer immunotherapy trials [163]. Overall, $\gamma \delta$ T-cell-based cancer immunotherapies hold high promise but still have room for improvement, and current efforts are now focusing on overcoming the main pitfalls through, for example, improving activation protocols, understanding $\gamma \delta \mathrm{TCR}$ diversity and receptor-ligand interactions, developing $\gamma \delta$ TCR chimeric antigen receptor (CAR)-T cells and exploring useful drug combinations [15,163,164].

\section{Pro-Tumour Functions of $\gamma \delta$ T Cells}

Interestingly, as mentioned above, the pro-tumour functions of $\gamma \delta \mathrm{T}$ cells appear to be mainly relevant in solid tumours. Tumour-promoting functions of $\gamma \delta \mathrm{T}$ cells are primarily mediated through the direct and indirect actions of $\gamma \delta \mathrm{T} 17$ cells, which can be the 
result of polarisation programming. Indeed, the presence of high levels of IL-17 has been detected in various cancer types, such as cervical cancer [170], breast cancer [134], ovarian cancer [171], hepatocellular carcinoma [172,173], non-small cell lung cancer [174,175] and neuroblastoma [176], where it is consistently associated with tumour-promoting functions.

One mechanism by which $\gamma \delta \mathrm{T}$ cells have been shown to induce pro-tumour functions is by negatively regulating other cancer-killing immune cells (Figure 3). For example, Peng et al. showed that breast tumour-infiltrating $\mathrm{V} \delta 1^{+} \mathrm{T}$ cells supressed $\mathrm{CD} 8^{+} \alpha \beta$ T-cell cytotoxicity and DC function [177], thus acting here as immune suppressors. Notably, cotransfer of these $\gamma \delta$ TILs together with cytotoxic $\mathrm{CD}^{+} \alpha \beta$ T cells abolished the anti-tumour effect of the $\mathrm{CD} 8^{+} \mathrm{T}$ cells in a melanoma mouse model [177]. Supporting these findings, Chen et al. reported that ovarian tumour-infiltrating $\gamma \delta \mathrm{T}$ cells recruited via the TME were primarily $\mathrm{V} \delta 1^{+} \gamma \delta \mathrm{T} 17$ cells, which in turn secreted large quantities of pro-inflammatory IL-17 and demonstrated the capacity for immunosuppression by inhibiting $\mathrm{CD} 4^{+}$naïve T-cell proliferation in vitro [37].

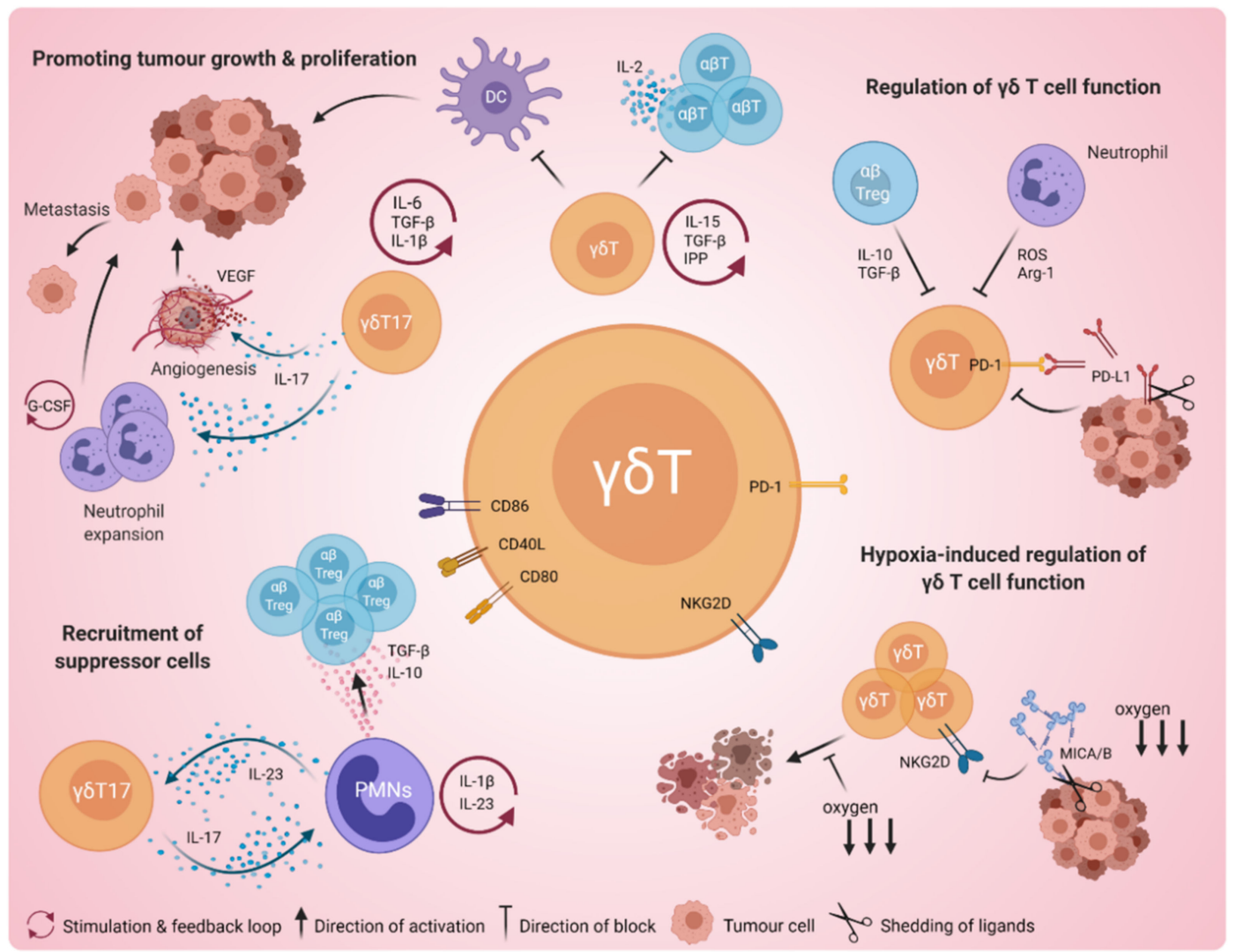

Figure 3. Pro-tumour functions of $\gamma \delta \mathrm{T}$ cells and the negative regulation of their anti-tumour capacity. Pro-tumour functions of $\gamma \delta$ T cells include direct immune suppressor functions blocking $\alpha \beta$ T-cell cytotoxicity and DC maturation, promoting angiogenesis and stimulating immune-suppressive neutrophil expansion. $\gamma \delta \mathrm{T}$ cells can recruit/promote suppressive polymorphonuclear cells (PMNs), facilitated by IL-17, IL-23 and IL-1 $\beta$ feedback loops. Negative regulation of $\gamma \delta$ T-cell anti-tumour activity can occur via PD-1/PD-L1 interaction induced by tumour cells, as well as suppressive activity by neutrophils and $\alpha \beta$ Tregs. Hypoxia-induced regulatory effects from the tumour microenvironment (TME) can induce tumour cell shedding of MICA/B to block NKG2D-mediated $\gamma \delta$ T-cell cytotoxicity. Arg-1, arginase-I; G-CSF, granulocyte colony-stimulating factor; ROS, reactive oxygen species; TGF- $\beta$, transforming growth factor- $\beta$; VEGF, vascular endothelial growth factor.

In support of their suppressor function, murine $\gamma \delta \mathrm{T}$ cells stimulated in vitro with TGF- $\beta$ and IL-15 were shown to express the FOXP3 transcription factor [178], resulting in immune suppressor functions similar to $\alpha \beta$ Tregs [179]. This cytokine combination alone is not sufficient to induce human $\gamma \delta$ Tregs from isolated peripheral blood mononuclear cell 
(PBMC) cultures [178]; however, additional stimulation with IPP was shown to successfully polarise $\mathrm{V} \gamma 9 \mathrm{~V} \delta 2 \mathrm{~T}$ cells into $\gamma \delta$ Tregs, expressing FOXP3 and being capable of eliciting suppressive effects against stimulated PBMCs [63]. In line with this, a classical regulatory phenotype in $\mathrm{V} \delta 1^{+} \mathrm{T}$ cells was induced by stimulation with a plate-bound anti-V $\delta 1$ antibody, promoting expression of regulatory markers FOXP3, CD25 and CTLA-4, as well as inducing functional suppression of $\mathrm{CD}^{+}$T-cell proliferation [180]. Additionally, TGF- $\beta 1$ production by $\mathrm{V} \delta 1^{+} \mathrm{T}$ cells can be involved in a positive feedback loop, sustaining FOXP3 expression and also leading to production of the anti-inflammatory cytokine IL-10 [180]. Importantly, many of these cytokines are found abundantly in the TME [181], with the potential of inducing $\gamma \delta \mathrm{T}$-cell polarisation, highlighting that there are multiple ways to induce a regulatory phenotype in $\gamma \delta$ T cells, in which the TME plays a key role. This adds an important level of complexity to the roles of $\gamma \delta \mathrm{T}$ cells in cancer immunity that will need to be considered in $\gamma \delta$ T-cell-based cancer immunotherapy.

$\gamma \delta \mathrm{T}$ cells can also regulate other immune cells to support tumour progression (Figure 3). The interaction of $\gamma \delta$ T cells with suppressive polymorphonuclear cells (PMNs, also known as myeloid-derived suppressor cells or MDSCs) is multi-faceted; while $\gamma \delta \mathrm{T} 17$ cells can recruit PMNs into the tumour [39], PMNs can in turn suppress cytotoxic $\gamma \delta \mathrm{T} 1$ cells [40] and can provide a source of IL-10 and TGF- $\beta$ to recruit Tregs, promoting immune suppression and tumour growth [182]. Notably, Wu et al., reported that $\mathrm{V} \delta 1^{+} \gamma \delta \mathrm{T} 17$ cells, which were found at higher numbers in colorectal cancer, were capable of enhancing PMN migration, proliferation and survival, and were correlated with colon tumour invasiveness and progression [39]. Furthermore, neutrophils were also found to be regulated by $\gamma \delta \mathrm{T} 17$ cells, promoting metastasis in a murine mammary tumour model [134]. Mechanistically, IL-1 $\beta$ from the TME was shown to elicit IL-17 production from $\gamma \delta$ TILs, leading to the granulocyte colony-stimulating factor (G-CSF)-dependent systemic expansion of neutrophils that suppress cytotoxic $\mathrm{CD} 8^{+} \mathrm{T}$ cells, allowing increased metastatic disease [134].

The promotion of angiogenesis is another key tumour-promoting effect of $\gamma \delta \mathrm{T} 17$ cells in solid cancers [43] (Figure 3). In mice, it was first demonstrated that tumour-infiltrating $\gamma \delta \mathrm{T}$ cells, polarised towards a $\gamma \delta \mathrm{T} 17$ phenotype by the TME, provided the main source of tumour IL-17 necessary to induce increased levels of angiogenic factors Ang-2 and VEGF, as well as increase blood vessel numbers [162]. Pro-angiogenic functions of $\gamma \delta T 17$ cells have been reported in tumour models of ovarian cancer and human papilloma virus (HPV)-induced squamous cell carcinoma [183,184]. Notably, in gall bladder cancer patient samples, IL-17 secreted from tumour-infiltrating $\gamma \delta \mathrm{T} 17$ cells was shown to induce tumour cell VEGF production and angiogenesis, and increased $\gamma \delta \mathrm{T} 17$ cell numbers were associated with reduced patient survival [173].

\section{Regulation of $\gamma \delta$ T-Cell Cancer Immunity}

The regulation of $\gamma \delta \mathrm{T}$ cells can play an important role in their overall function in cancer immunity, whereby factors negatively regulating their anti-tumour activity ultimately promote tumour progression. One such example includes the hypoxia-induced immune evasion of solid cancers (Figure 3). Hypoxia can be prominent in the TME of solid tumours and was found to be a negative regulator of $\gamma \delta$ T-cell anti-tumour function [66]. For oral cancer, Sureshbabu et al. recently demonstrated that hypoxia significantly reduced the cytolytic activity of patient-derived $\gamma \delta \mathrm{T}$ cells [42]. Interestingly, findings in human breast cancer revealed that $\gamma \delta \mathrm{T}$ cells primed by hypoxic conditions in vitro had enhanced cytolytic activities. However, this enhanced effect could not overcome the hypoxia-induced resistance of a breast cancer cell line (MCF-7) towards NKG2D-mediated $\gamma \delta$ T-cell cytotoxicity [66]. The authors hypothesised that the increased shedding of MICA/B ligands from the tumour cell surface was causing the resistance to $\gamma \delta$ T-cell-mediated killing. Very recently, Park et al., confirmed a similar effect of hypoxia-induced immune evasion in a model of brain cancer [64]. Again, here, they showed reduced infiltration of cytotoxic $\gamma \delta \mathrm{T}$ cells into tumours affected by hypoxia in the TME. 
Metabolites in the TME also play an important role in regulating the infiltration and function of the different effector subtypes, $\gamma \delta \mathrm{T} 1$ and $\gamma \delta \mathrm{T} 17$, thereby impacting $\gamma \delta \mathrm{T}$-cell tumour immune responses. $\gamma \delta \mathrm{T} 1$ cells display a preference for glycolysis, whereas $\gamma \delta \mathrm{T} 17$ cells are dependent on oxidative phosphorylation and have increased lipid uptake [34]. As such, it was shown that $\gamma \delta \mathrm{T} 1$ cells pre-incubated in high glucose levels and injected into breast tumours displayed increased anti-tumour capacity. Conversely, a lipid-rich TME increased the number of $\gamma \delta \mathrm{T} 17 \mathrm{TILs}$, and lipid uptake promoted $\gamma \delta \mathrm{T} 17$ cell proliferation and enhanced melanoma tumour growth [34]. Due to the high demand of cancer cells for glucose (the 'Warburg effect'), the resulting low glucose levels in the TME, coupled with high levels of other metabolites such as lipids or lactate, which can also negatively impact T-cell effector function [185], are likely to select for specific $\gamma \delta$ T-cell subsets in favour of reduced anti-tumour immunity and increased tumour progression $[135,186]$. Strategies to modulate metabolite levels in the TME would therefore be highly attractive to enhance T-cell-mediated tumour cytotoxicity.

Immune checkpoint receptors act as another important regulatory mechanism for $\gamma \delta$ T-cell function. For instance, PD-1 is an immune checkpoint receptor expressed on most T cells, including $\gamma \delta \mathrm{T}$ cells, which upon ligand/antigen engagement acts as an 'off switch' to negatively regulate T-cell function [187]. Its ligand, PD-L1, was found to be constitutively expressed on cancer cells [188], as well as being present in the TME of several cancers [188-190]. As PD-1 is often present on activated and tumour-infiltrating $\gamma \delta \mathrm{T}$ cells, the presence of PD-L1 in the TME and expressed on tumour cells can limit $\gamma \delta$ T-cell antitumour activity $[188,191,192]$ (Figure 3). Therefore, checkpoint inhibitor immunotherapy is being explored to enhance the anti-tumour function of $\gamma \delta \mathrm{T}$ cells [191,193-195]. For example, as a strategy to boost the anti-tumour activity of V $\gamma 9 \mathrm{~V} \delta 2 \mathrm{~T}$ cells, the use of PD-1 blockade in conjunction with PAg stimulation has been employed [196,197], aiming to neutralise the effect of the PAg stimulation-related upregulation of PD-1 on $\gamma \delta$ T cells [198]. Interestingly, while use of anti-PD-L1 antibodies was found to indeed increase the antitumour effect of $\gamma \delta \mathrm{T}$ cells [41,194], this was not mediated by an increase in $\gamma \delta \mathrm{T}$-cell cytotoxic activity, but rather by $\gamma \delta$ T-cell-mediated ADCC induced by the tumour-targeting antibody [41]. On the other hand, PD-1 blockade was shown to significantly increase IFN- $\gamma$ production in $\gamma \delta \mathrm{T}$ cells, although this required the prior activation of $\gamma \delta \mathrm{T}$ cells or sensitisation of target cells [199].

Similarly to the immune checkpoint molecules, expression of the metabolic enzyme indoleamine-2,3-dioxygenase (IDO) in cancer cells can promote an immunosuppressive shift in the TME [200]. Mechanistically, increased IDO activity promotes tryptophan catabolism, leading to a depletion of this essential amino acid in the TME and to an accumulation of tryptophan metabolites such as kynurenine, which was shown to decrease $\gamma \delta$ T-cell cytotoxic capacity [201]. As such, IDO inhibitors were shown to improve the cytotoxicity of $\mathrm{V} \gamma 9 \mathrm{~V} \delta 2 \mathrm{~T}$ cells against human pancreatic [201] and breast cancer cells [202]. These findings could be particularly relevant for patients with triple-negative breast cancer, of which only a minority benefited therapeutically from PD-1 blockade [203]. Recent efforts have been made to explore the value of IDO blockade in cancer immunotherapy clinical trials [204].

Other immune cells can also negatively regulate $\gamma \delta \mathrm{T}$ cells (Figure 3). For example, neutrophils have been reported to suppress $\gamma \delta$ T-cell function [205]. On the one hand, it was shown that zoledronic acid-activated neutrophils could potently inhibit peripheral blood $\mathrm{V} \gamma 9 \mathrm{~V} \delta 2^{+} \mathrm{T}$ cells, which was mechanistically linked to neutrophil-derived hydrogen peroxide, serine protease and arginase-I activity [206]. Interestingly, however, a more recent study in mice found that neutrophils selectively inhibit pro-tumour $\gamma \delta \mathrm{T} 17$ cells via production of reactive oxygen species (ROS), inducing oxidative stress and thereby mediating anti-tumour effects [207]. Therefore, the roles of neutrophils in cancer immunity appear to be pleiotropic and likely context-dependent. It was also shown in hepatocellular carcinoma patients that $\alpha \beta$ Tregs can suppress the cytotoxic function of $\gamma \delta \mathrm{T} 1$ cells in an IL-10- and TGF- $\beta$-dependent manner [208]. 
Interestingly, the local microbiota may play a role in regulating the response of $\gamma \delta \mathrm{T} 17$ cells against tumour cells. In a genetically engineered lung cancer model driven by KRAS and p53, the lung microbiota induced the proliferation and activation of $\gamma \delta \mathrm{T} 17$ cells to promote inflammation and tumour cell proliferation, where antibiotics or germ-free conditions suppressed these effects [175]. However, these findings are in contrast to an earlier study reporting that the lung microbiota was protective against lung tumour development by B16-F10 melanoma or Lewis lung carcinoma cells [209]. Here, it was suggested that $\gamma \delta T 17$ cells mediated this anti-tumour effect, as antibiotic treatment impaired $\gamma \delta \mathrm{T} 17$ cell function and enhanced tumour development, and this could be reversed by adoptive transfer of untreated $\gamma \delta$ T cells or administration of IL-17 [209].

\section{5. $\gamma \delta$ T-Cell Lymphoma/Leukaemia}

The malignant transformation and outgrowth of $\gamma \delta$ T cells seems to be a relatively rare event as most recognised T-cell neoplasms are composed of $\alpha \beta$ T cells. Entities arising from $\gamma \delta$ T cells include hepatosplenic T-cell lymphoma (HSTL), primary cutaneous $\gamma \delta$ T-cell lymphoma (PCGDTL), monomorphic epitheliotropic intestinal T-cell lymphoma (MEITL), enteropathy-associated T-cell lymphoma (EATL), T-cell large granular lymphocytic leukaemia (T-LGLL) and T-ALL (Table 1). For the first three entities (HSTL, PCGDTL, MEITL), a large proportion/majority of the cases arise from $\gamma \delta \mathrm{T}$ cells, although $\alpha \beta$ T-cell forms are also described, while for the latter three entities (EATL, T-LGLL, T-ALL), $\gamma \delta$ T-cell forms are a rarity.

HSTL is an aggressive disease that primarily affects younger adults (median age of 34 years), with a higher incidence in males $(\approx 71 \%)[210,211]$. The disease is largely derived from $\gamma \delta$ T cells, although up to $20 \%$ of HSTL cases express the $\alpha \beta$ TCR [210,212], and interestingly, these cases occur more frequently in women [213]. HSTL manifests mainly in the spleen, liver and, in the majority of cases, also to a small degree in the bone marrow. The disease progresses rapidly with a median survival of 13 months [214,215]. There is a striking association with a history of therapeutic immunosuppression in HSTL.

Malignant $\gamma \delta$ T cells can also arise in or home to the skin, and PCGDTL constitutes a separate entity among the cutaneous T-cell lymphomas (CTCLs) [212]. PCGDTL was formerly a subset of subcutaneous panniculitis-like T-cell lymphoma (SPTCL), which is now only reserved for the $\alpha \beta$ cases, while the PCGDTLs are prognostically distinct [216]. This rare disease makes up $<1 \%$ of all primary CTCLs and has a highly aggressive course, with a median survival of 15-31 months $[217,218]$. $\gamma \delta$ T-cell-derived CTCLs have a significantly lower median survival as compared to $\alpha \beta$ TCR $^{+}$CTCL patients (15 months and 166 months, respectively) [218]. PCGDTL is also associated with a slight male predominance $[217,218]$.

The intestinal T-cell lymphomas EATL and MEITL are also rare but aggressive diseases [212]. EATL is strongly associated with celiac disease and is predominantly of the $\alpha \beta$ T-cell subtype $[219,220]$, although cases of $\gamma \delta \mathrm{TCR}^{+}$EATL have been reported $[221,222]$. MEITL, on the other hand, has no association with celiac disease, and a larger proportion of cases can arise from $\gamma \delta$ T cells, varying in reports ranging from $25-80 \%$ of cases expressing $\gamma \delta$ TCR, with the remaining cases having an $\alpha \beta$ phenotype, presenting as TCR silent or, interestingly, co-expressing both $\alpha \beta$ and $\gamma \delta$ TCRs [223-225]. Both EATL and MEITL present more frequently in males (EATL with a slight male predominance [226-228], MEITL with a male to female ratio of 2:1 [223-225,229]). As aggressive and treatment-refractory diseases, both EATL and MEITL show a median OS of 7 months [223,224,226,230].

LGLL is a rare lymphoproliferative disorder that can arise from $\mathrm{T}$ or NK cell lineages, and unlike the aforementioned diseases, it has a rather indolent course. Nevertheless, the associated cytopenias and autoimmune phenomena make it a highly symptomatic disease. The most frequent form of T-LGLL $\left(\approx 85 \%\right.$ of cases) is derived from $\alpha \beta \mathrm{TCR}^{+}$ $\mathrm{CD}^{+}$cytotoxic T cells, where chronic NK-LGLL comprises $<10 \%$ of cases [231]. $\gamma \delta \mathrm{T}-$ LGLL represents an even smaller subset of the overall cases, and, perhaps surprisingly given the aggressive nature of most other $\gamma \delta$ T-cell derived malignancies, $\gamma \delta$ T-LGLL has a clinical presentation and an indolent course that is similar to its $\alpha \beta \mathrm{TCR}^{+}$counterpart 
(62-114 months median OS for both) [232-234]. No sex-specific biases in T-LGLL diagnoses have been found $[232,233,235]$.

T-ALL arises from the malignant transformation of immature $\mathrm{T}$ cells in the thymus or bone marrow, and it occurs most frequently in children and young adults. Approximately $10-15 \%$ of all T-ALL cases express the $\gamma \delta$ TCR [236], which is perhaps unexpectedly high given that $\gamma \delta$ thymocytes comprise only $\approx 1 \%$ of T cells in the human thymus [237], suggesting that $\gamma \delta$ thymocytes may be more susceptible to transformation compared to $\alpha \beta$ thymocytes [16]. Notably, the 5-year OS for patients with $\gamma \delta$ T-ALL was significantly lower as compared to other T-ALL patients (66.7\% vs. 95.7\%) [237], and increased splenomegaly and white blood cell counts were reported in adult $\gamma \delta$ T-ALL patients [236]. Reports also suggest that there is an association of male predominance in $\gamma \delta$ T-ALL $[236,237]$.

\subsection{Development of $\gamma \delta$ T-Cell Lymphoma/Leukaemia}

The transformation process of a $\gamma \delta \mathrm{T}$ cell into a malignant clone is, like for other cell types, a complex and multi-factorial process. In contrast to many other types of haematopoietic cells, T-cell oncogenesis involves overcoming the safeguarding mechanism of TCR/MHC niche-mediated cross-clonal control, which is a part of T-cell homeostasis [238]. On the basis of disease aetiology across all $\gamma \delta$ T-cell lymphoma/leukaemia subtypes, there is evidence that a chronic inflammatory or immune-suppressed environment and persistent activation signals are key triggers for $\gamma \delta$ T-cell transformation.

Around $20 \%$ of HSTL cases arise in patients with pre-existing immune dysregulatory disorders, such as inflammatory bowel disease (IBD), autoimmune disorders (systemic lupus, rheumatoid arthritis), infections (malaria), haematological malignancies (Hodgkin lymphoma) or long-term immunosuppression after organ transplantation $[210,211,239]$. Immunosuppressive therapies given to patients with such conditions, such as thiopurines (e.g., azathioprine or 6-mercaptopurine [6-MP]) for IBD patients, have been linked to the development of HSTL $[240,241]$. Concurrent administration of other agents such as TNF- $\alpha$ inhibitor therapy appears to increase the risk of HSTL development, although this observation may be confounded by the need for increased therapy in patients with more severe conditions, increased inflammation and chronic antigenic stimulation [210,240]. EATL is strongly linked with celiac disease, and therefore with autoimmunity and inflammation of the intestine, although the majority of cases derive from $\alpha \beta$ T cells $[219,220]$. A large study of 53 PCGDTL patients also revealed that additional pre-existing conditions involved in immune dysregulation were common, such as lymphoproliferative disorders (Hodgkin lymphoma, B-cell non-Hodgkin lymphoma, CLL), hypothyroidism secondary to Hashimoto thyroiditis, Crohn's disease, alopecia areata, celiac disease/uveitis/arthritis and sarcoidosis [217]. Fitting the concept of narrowed clonal repertoires promoting the outgrowth of malignant T-cell clones (homeostasis concept) [238], any therapy that reduces the spectrum of clonal T-cell diversity may promote $\gamma \delta$ T-cell oncogenesis. T-LGLL is also strongly linked to co-existing autoimmune diseases, with the most common being rheumatoid arthritis, and others including systemic lupus erythematosus, Felty's syndrome, chronic IBD, autoimmune haemolytic anaemia and other haematological neoplasms (myelodysplastic syndrome, B-cell malignancies, aplastic anaemia) [231,242]. Studies comparing $\alpha \beta$ and $\gamma \delta$ T-LGLL revealed that the occurrence of such immune dysregulatory conditions is similar in patients with either subtype [232-234].

Therefore, at least in mature $\gamma \delta \mathrm{T}$ cells, the co-occurrence of inflammatory or immunemodulating disorders in a subset of patients with $\gamma \delta$ T-cell lymphoma/leukaemia, irrespective of their origin or main site of infiltration, suggests that chronic inflammation and activation signals could be common states driving the transformation process. Of course, these diseases also arise de novo in many cases, but such inflammatory or immunosuppressive environments may accelerate initiating events (e.g., through accumulating reactive oxygen species) to allow damaged cells to persist. Indeed, we previously reported that patients with newly diagnosed rheumatoid arthritis have expanded CD8 ${ }^{+} \mathrm{T}$-cell clones harbouring somatic mutations linked to cell proliferation [243], and also that STAT3 mutations 
were significantly associated with rheumatoid arthritis in T-LGLL patients [244]. Notably, particularly IL-17-producing $\gamma \delta \mathrm{T}$ cells have been implicated in the pathogenesis of inflammatory and autoimmune diseases [245], highlighting the possibility of a self-promoting environment ultimately favouring transformation.

The specific $\gamma \delta$ T-cell subsets that undergo transformation to drive these diseases vary across the different lymphoma/leukaemia entities. In HSTL patients, $90 \%$ of cases are derived from the V $\delta 1$ subset [210], which is the main $\gamma \delta$ T-cell subtype occupying both the liver and spleen in humans (Figure 1). The same is true for $\gamma \delta$ T-ALL, in which $80 \%$ of patients have a $\mathrm{V} \delta 1^{+}$disease [246]. This is marginally higher but closely in line with what would be expected on the basis of normal healthy proportions in the human thymus, where $60-75 \%$ of $\gamma \delta \mathrm{T}$ cells are $\mathrm{V} \delta 1^{+}$and $20-25 \%$ are $\mathrm{V} \delta 2^{+}[247,248]$. A report on a small number of patients revealed that patients with MEITL also present with V $81^{+}$disease [249], which is perhaps expected given that the $\mathrm{V} \delta 1$ subtype is also the most prevalent in mucosal tissues such as the intestine (Figure 1). Interestingly, while it was previously thought that PCGDTLs arise from the V $\delta 2$ subtype [250], recently, Daniels et al. interrogated different layers of the skin to demonstrate that disease arising from the upper epidermal/dermal layers is specifically of the V $\delta 1$ subtype, whereas disease originating from lower subcutaneous adipose tissue is $\mathrm{V} \delta 2^{+}$, consistent with their normal distribution in healthy skin [251]. The authors also revealed that the V 81 lymphomas had an accompanying $\mathrm{V} \gamma 3$ or $\mathrm{V} \gamma 5$ chain, whereas unexpectedly, all $\mathrm{V} \delta 2$ cases had an accompanying $\mathrm{V} \gamma 3$ chain [251]. No differences in patient prognosis between the two subtypes were identified [251]. In cases of $\gamma \delta \mathrm{T}$ LGLL, both subtypes have been reported, with a distribution of $48-70 \% \mathrm{~V} \delta 2^{+}$and $20-43 \%$ $\mathrm{V} \delta 1^{+}[232,233]$. This is again mostly in line with the proportions of $\gamma \delta \mathrm{T}$-cell subsets in healthy adult peripheral blood, which are reported as $80-85 \% \mathrm{~V} \delta 2^{+}$and $10-20 \% \mathrm{~V} \delta 1^{+}$[232], with a potential slight bias towards V $\delta 1$ cells in $\gamma \delta$ T-LGLL. Interestingly, there have been some reports of rare $\gamma \delta$ T-cell lymphoma/leukaemia cases arising from V $\delta 3$ or V $\delta 6$ subsets in patients with MEITL, $\gamma \delta$ T-LGLL and $\gamma \delta$ T-ALL [232,246,252]. Overall, it appears that the $\gamma \delta \mathrm{T}$ cell of origin in these diseases is largely dictated by the physiological proportion of $\gamma \delta$ T-cell subsets in the tissue where the disease arises.

\subsection{Common Genetic Aberrations}

Irrespective of the sites/tissues in which $\gamma \delta$ T-cell transformation takes place, the genetic aberrations that frequently occur across the various $\gamma \delta$ T-cell lymphoma/leukaemia entities have distinct commonalities. Interestingly, gains of chromosome 7q are observed in patients from almost all $\gamma \delta$ T-cell cancer subtypes (Table 1). Notably, isochromosome $7 \mathrm{q}$ (gain of $7 \mathrm{q}$ and concomitant loss of $7 \mathrm{p}$ ) is detected in up to $70 \%$ of HSTL patients $[210,240,253]$, highlighting that this event is an early driver of disease development. It is not completely understood how 7q gains drive the pathogenesis of HSTL, but it has been linked to the upregulation of genes including $A B C B 1, R U N D C 3 B$ and PPP1R9A [254]. Various other chromosomal losses are also observed across $\gamma \delta$ T-cell lymphoma/leukaemia patients (Table 1), with losses of 9p occurring in PCGDTL, EATL and MEITL patients, potentially linked to the loss of tumour suppressors $C D K N 2 A / B$ [255]. In line with $\alpha \beta$ T-ALL and other acute leukaemias, complex cytogenetic abnormalities/translocations are also common in $\gamma \delta$ T-ALL (Table 1). Interestingly, the fusion-proteins SET-NUP214 and CALM-AF10 were identified as specific to $\gamma \delta$ T-ALL and were found to be associated with chemotherapy resistance and poor prognosis, respectively [256,257]. Chromosomal aberrations (gains, losses, translocations) may therefore represent common, primary initiating events in $\gamma \delta$ T-cell transformation, predisposing the $\gamma \delta \mathrm{T}$ cells to acquiring additional driving mutations. This phenomenon is also observed in other mature T-cell malignancies, such as recurrent rearrangements at chromosome 14 in T-cell prolymphocytic leukaemia (T-PLL) and the driver fusion-protein oncogene NPM-ALK in anaplastic large cell lymphoma (ALCL) $[258,259]$.

Strikingly, there are clear commonalities in the signalling pathways most frequently and recurrently affected by somatic mutations across the $\gamma \delta$ T-cell malignancies, with the key pathways affected including JAK-STAT, epigenetic regulation, RAS-MAPK and 
AKT-mTOR (Table 1). Perhaps unsurprisingly, these pathways are all critical for $\gamma \delta$ T-cell development, effector function and/or TCR signalling [33,260-262]. The hyperactivation of JAK-STAT, RAS-MAPK and AKT-mTOR signalling would therefore confer persistent proliferative and survival signals to the $\gamma \delta \mathrm{T}$ cancer cells, whereas alterations to chromatin modifier proteins, frequently seen also in other haematopoietic cancers [263], can further dysregulate the expression of oncogenes and tumour suppressors and/or alter lineagespecific factors via manipulation of the chromatin landscape. The latter, particularly altered genomic methylation profiles, appears to be an especially important driver in $\gamma \delta$ T-cell cancers, as evidenced by the relatively frequent loss-of-function mutations observed in the histone methyltransferase SETD2 and the DNA demethylase TET2 (Table 1). In addition, there is a clear dominance of hyperactivating JAK-STAT gene mutations across the $\gamma \delta$ T-cell lymphoma/leukaemia entities, particularly in STAT5B, STAT3, JAK3 and JAK1. Notably, STAT5 and STAT3 also have clear roles in regulating the epigenetic and chromatin landscape [264]. Indeed, we have shown that the most frequent gain-of-function STAT5B mutation in T-cell cancers, N642H [265], induces considerable alterations to DNA methylation as well as transcriptional profiles in T cells [266], and is sufficient to drive the transformation of $\gamma \delta \mathrm{T}$ cells and induce $\gamma \delta \mathrm{T}$-cell neoplasia in mice [267].

Table 1. Cancer entities arising from $\gamma \delta \mathrm{T}$ cells and their key genetic aberrations.

\begin{tabular}{|c|c|c|c|c|c|c|}
\hline $\begin{array}{l}\text { Disease } \\
\text { Subtype }\end{array}$ & $\begin{array}{l}\text { Median } \\
\text { Survival }\end{array}$ & Disease Site & Chromosomal Lesions & $\begin{array}{l}\text { Dysregulated } \\
\text { Pathways }\end{array}$ & $\begin{array}{c}\text { Genes Frequently } \\
\text { Affected }\end{array}$ & Ref. \\
\hline \multirow{3}{*}{ HSTL } & \multirow{3}{*}{13 months } & \multirow{3}{*}{ Spleen, liver } & \multirow{3}{*}{$\begin{array}{l}\text { Isochromosome } 7 q, \\
\text { trisomy } 8\end{array}$} & Epigenetic modifiers & $\begin{array}{c}\text { SETD2, INO80, TET3, } \\
\text { SMARCA2 }\end{array}$ & \multirow{3}{*}{$\begin{array}{l}{[214]} \\
{[215]} \\
{[268]}\end{array}$} \\
\hline & & & & JAK-STAT & STAT5B, STAT3 & \\
\hline & & & & AKT-mTOR & PIK3CD & \\
\hline \multirow{3}{*}{ MEITL } & \multirow{3}{*}{7 months } & \multirow{3}{*}{ Intestine } & \multirow{3}{*}{$\begin{array}{c}\text { Gain of } 8 \mathrm{q} 24(M Y C), 1 \mathrm{q}, 7 \mathrm{q} \text { or } \\
9 \mathrm{q} ; \text { loss of } 8 \mathrm{p}, 16 \mathrm{q}, 11 \mathrm{q} \text { or } \\
9 \mathrm{p} 21.3(C D K N 2 A / B)^{*}\end{array}$} & JAK-STAT & STAT5B, JAK1, JAK3 * & \multirow{3}{*}{$\begin{array}{l}{[222]} \\
{[229]} \\
{[269]} \\
{[255]}\end{array}$} \\
\hline & & & & RAS-MAPK & $K R A S, N R A S, B R A F^{*}$ & \\
\hline & & & & Epigenetic modifiers & $\begin{array}{c}\text { SETD2, TET2, YLPM1, } \\
\text { CREBBP * }\end{array}$ & \\
\hline \multirow{4}{*}{ PCGDTL } & \multirow{4}{*}{$\begin{array}{l}\text { 15-31 } \\
\text { months }\end{array}$} & \multirow{4}{*}{ Skin } & \multirow{4}{*}{$\begin{array}{c}\text { Gain of } 1 q, 15 q \text { or } 7 q \\
\text { loss of } 9 p \text { or } \\
18 q\end{array}$} & RAS-MAPK & $K R A S, N R A S, M A P K 1$ & \multirow{4}{*}{$\begin{array}{l}{[217]} \\
{[218]} \\
{[251]}\end{array}$} \\
\hline & & & & JAK-STAT & $\begin{array}{c}\text { STAT5B, SOCS1, JAK3, } \\
\text { STAT3 }\end{array}$ & \\
\hline & & & & Epigenetic modifiers & $\begin{array}{c}\text { ARID1A, } \\
\text { TRRAP, TET2, KMT2D }\end{array}$ & \\
\hline & & & & Cell cycle & CDKN2A & \\
\hline $\begin{array}{c}\gamma \delta \\
\text { T-LGLL }\end{array}$ & $\begin{array}{l}62-114 \\
\text { months }\end{array}$ & Blood & $\begin{array}{c}\text { Rare; } \\
\text { gain of 7p21 and loss of Chr Y } \\
\text { or Chr } 6 \text { reported }\end{array}$ & JAK-STAT & STAT3, STAT5B * & $\begin{array}{l}{[233]} \\
{[232]} \\
{[234]} \\
{[244]}\end{array}$ \\
\hline \multirow{3}{*}{ EATL } & \multirow{3}{*}{7 months } & \multirow{3}{*}{ Intestine } & \multirow{3}{*}{$\begin{array}{c}\text { Gain of } 1 \mathrm{q}, 7 \mathrm{q} \text { or } 9 \mathrm{q} ; \text { loss of } 9 \mathrm{p} \\
\text { or } 17 \mathrm{p} 12- \\
13.2(T P 53)\end{array}$} & JAK-STAT & $\begin{array}{l}\text { SOCS1, JAK1, STAT3, } \\
\text { JAK3, STAT5B * }\end{array}$ & \multirow{3}{*}{$\begin{array}{l}{[222]} \\
{[219]} \\
{[269]}\end{array}$} \\
\hline & & & & Epigenetic modifiers & TET2, SETD2 * & \\
\hline & & & & Survival & $D A P K 3$ * & \\
\hline \multirow{3}{*}{$\begin{array}{c}\gamma \delta \\
\text { T-ALL }\end{array}$} & \multirow{3}{*}{$\begin{array}{c}\text { 5-year OS: } \\
67 \%\end{array}$} & \multirow{3}{*}{ Thymus, blood } & $\begin{array}{l}\text { Complex cytogenetic } \\
\text { abnormalities; }\end{array}$ & - & $\begin{array}{l}\text { Gene fusions: } \\
\text { SET-NUP214, } \\
\text { CALM-AF10 }\end{array}$ & \multirow{3}{*}{$\begin{array}{l}{[237]} \\
{[256]} \\
{[257]} \\
{[270]} \\
{[271]}\end{array}$} \\
\hline & & & $\begin{array}{c}\text { loss of } 6 \mathrm{q} 13- \\
23 \text { or } 12 \mathrm{p} 11-13 ; \\
\text { translocations } \mathrm{t}(11 ; 14) \text { or }\end{array}$ & JAK-STAT & $\begin{array}{c}\text { IL7R, JAK3, STAT5B, } \\
\text { JAK1 * }\end{array}$ & \\
\hline & & & $\mathrm{t}(10 ; 11)$ & AKT-mTOR (via CK2) & - & \\
\hline
\end{tabular}

* including, but not restricted to, $\gamma \delta \mathrm{TCR}^{+}$cases due to their rarity in the disease and/or lack of specific analyses. OS, overall survival; Chr, chromosome; CK2, casein kinase 2; HSTL, hepatosplenic T-cell lymphoma; MEITL, monomorphic epitheliotropic intestinal T-cell lymphoma; EATL, enteropathy-associated T-cell lymphoma; PCGDTL, primary cutaneous $\gamma \delta$ T-cell lymphoma; T-LGLL, T-cell large granular lymphocytic leukaemia; T-ALL, T-cell acute lymphoblastic leukaemia. 


\subsection{Current Treatment Options and Promising Therapeutic Directions}

Despite T-cell neoplasms being a heterogeneous disease group, many of our current chemotherapy approaches are rather uniformly adopted from those developed for aggressive B-cell lymphomas [272-276]. We have just recently begun to address certain entities more specifically. Generally, current standard regimens of chemotherapy, including those applied to $\gamma \delta$ T-cell lymphoma/leukaemia, are mostly anthracycline-based and can additionally involve substances like etoposide, ifosfamide, methotrexate, asparaginase and others [274,277-283]. The therapeutic goal at first-line treatment is to achieve a complete remission (CR) status, which can then be followed by a consolidating autologous or allogeneic stem cell transplantation in eligible patients. This to date remains the only effective, potentially curative treatment modality. Such strategies of early intensified therapy are particularly applied to the high-risk diseases EATL, MEITL, HSTL and PCGDTL. In some cases, successful long-term remission following this strategy has been reported for $\gamma \delta$ HSTL patients $[284,285]$. Unfortunately, however, a considerable number of patients do not respond well to the current chemotherapy treatments available, and thus fail to qualify for these consolidating measures $[211,253,286]$. Clinical investigations of new therapies for $\gamma \delta$ T-cell lymphoma patients are challenging due to the rarity of the diseases, imposing difficulties in patient recruitment and tumour sampling for translational studies. Furthermore, to date, there are no robust pre-clinical models for $\gamma \delta$ T-cell lymphoma available to facilitate testing of targeted therapies.

Due to the lack of targeted therapy options, treatments approved for other (mainly $\alpha \beta$ ) peripheral T-cell lymphomas (PTCLs) or B-cell lymphomas are repurposed for use in $\gamma \delta$ T-cell lymphoma/leukaemia patients. Newer, more targeted treatment options that are clinically approved are being explored in trials for relapsed/refractory PTCL or as combinations in first-line settings. These trials include patients with $\gamma \delta$ T-cell lymphoma/leukaemia, as trials dedicated only to these entities are usually not feasible. The substance classes being tested include folate metabolite inhibitors (methotrexate, pralatrexate), oral inhibitors of phosphoinositide-3 kinase (PI3K; duvelisib, copanlisib, tenalisib) [287], JAK inhibitors, antibody-drug conjugates (brentuximab vedotin; only FDA-approved when CD30 is expressed in $>10 \%$ of tumour cells), histone deacetylase (HDAC) inhibitors (romidepsin, belinostat, chidamide) [288] or DNA-demethylating agents. As a notable example for the efficacy of HDAC inhibitors, Wang et al. recently reported an HSTL case where conventional chemotherapy as induction therapy failed to control disease progression [289]. Strikingly, upon treatment with oral chidamide combined with chemotherapy (ifosfamide, carboplatin, etoposide), followed by chidamide maintenance, the patient achieved a CR for 9 months. Other much older alternative treatment options for unresponsive cases of HSTL include purine analogues. There have been several reports of successful treatment with 2'-deoxycoformycin (pentostatin) that resulted in short-term relief from symptoms and tumour cell clearance in blood [290-293]. There are newer purine analogues such as cladribine that present with a better cytotoxic profile and that are also being explored for further use in some other PTCLs.

Overall, new therapeutic options are urgently needed for these aggressive $\gamma \delta \mathrm{T}$-cell diseases. Given the more recent advances in understanding the molecular profiles and events driving these malignancies (Table 1) [215,251,269,294], it is perhaps not surprising that HDAC and PI3K inhibitors show efficacy, and drugs targeting the JAK-STAT or RASMAPK pathways also hold promise in certain $\gamma \delta$ T-cell cancer entities. The more we understand the driving mechanisms and molecular properties of these rare diseases, the better we can move forward in designing specifically targeted therapies to maximise patient outcomes. However, it must be kept in mind that the greatest challenge for clinical trials in these rare entities remains the limited patient numbers and resulting difficulties to recruit enough patients at the study site level. Therefore, advancements in suitable pre-clinical models as well as the compassionate use of potentially suitable targeted therapies will be important, and efforts should be made to make drug development more attractive for these rare diseases. 


\section{Conclusions}

Recent years have seen a large step forward in both our understanding of the roles of human $\gamma \delta \mathrm{T}$ cells in cancer immunity, as well as in our understanding of the genetic and molecular basis of aggressive $\gamma \delta \mathrm{T}$-cell leukaemia/lymphoma. These new insights will pave the way for considerable advancements in the years ahead, especially regarding the development of V $\delta 1 \mathrm{~T}$ cells as tools for adoptive $\gamma \delta \mathrm{T}$-cell immunotherapy for cancer patients. Nevertheless, it will be important to continue to dissect the pro-tumour functions of $\gamma \delta \mathrm{T} 17$ cells, particularly regarding polarisation triggers in the human context and the negative impact this could play on their therapeutic utility. Furthermore, new therapeutic strategies are urgently needed for patients suffering from incurable $\gamma \delta$ T-cell leukaemia/lymphoma, and current research focusing on identifying and targeting common dysregulated pathways, as well as the development of new faithful pre-clinical models, should hopefully soon lead to new breakthroughs to help these patients.

Author Contributions: Conceptualisation, H.A.N., S.S.; writing-original draft preparation, H.A.N., S.S., T.W.; writing—review and editing, H.A.N., S.S., R.M., V.B., M.H., S.M. All authors have read and agreed to the published version of the manuscript.

Funding: H.A.N. and R.M. were supported by the Austrian Science Fund (FWF) grant SFB-F06109. S.S., M.H., S.M. and H.A.N. were supported under the frame of ERA PerMed (JAKSTAT-TARGET), and M.H. and R.M. were supported under the frame of ERA-NET (ERANET-PLL). Open Access Funding by the Austrian Science Fund (FWF).

Acknowledgments: Figures were created using BioRender.com.

Conflicts of Interest: The authors declare no conflict of interest.

\section{References}

1. Hayday, A.C. $\gamma \delta$ T Cell Update: Adaptate Orchestrators of Immune Surveillance. J. Immunol. 2019, 203, 311-320. [CrossRef] [PubMed]

2. Ribot, J.C.; Lopes, N.; Silva-Santos, B. $\gamma \delta$ T cells in tissue physiology and surveillance. Nat. Rev. Immunol. 2021, 21, $221-232$. [CrossRef]

3. Kohlgruber, A.C.; Gal-Oz, S.T.; LaMarche, N.M.; Shimazaki, M.; Duquette, D.; Koay, H.F.; Nguyen, H.N.; Mina, A.I.; Paras, T.; Tavakkoli, A.; et al. $\gamma \delta \mathrm{T}$ cells producing interleukin-17A regulate adipose regulatory T cell homeostasis and thermogenesis. Nat. Immunol. 2018, 19, 464-474. [CrossRef] [PubMed]

4. Nielsen, M.M.; Witherden, D.A.; Havran, W.L. $\gamma \delta$ T cells in homeostasis and host defence of epithelial barrier tissues. Nat. Rev. Immunol. 2017, 17, 733-745. [CrossRef] [PubMed]

5. Papotto, P.H.; Yilmaz, B.; Silva-Santos, B. Crosstalk between $\gamma \delta$ T cells and the microbiota. Nat. Microbiol. 2021, 6, 1110-1117. [CrossRef]

6. Silva-Santos, B.; Serre, K.; Norell, H. $\gamma \delta$ T cells in cancer. Nat. Rev. Immunol. 2015, 15, 683-691. [CrossRef]

7. Hayday, A.C.; Vantourout, P. The Innate Biologies of Adaptive Antigen Receptors. Annu. Rev. Immunol. 2020, 38, 487-510. [CrossRef] [PubMed]

8. Hayday, A.C. [gamma][delta] cells: A right time and a right place for a conserved third way of protection. Annu Rev. Immunol. 2000, 18, 975-1026. [CrossRef]

9. Baum, T.P.; Hierle, V.; Pasqual, N.; Bellahcene, F.; Chaume, D.; Lefranc, M.P.; Jouvin-Marche, E.; Marche, P.N.; Demongeot, J. IMGT/GeneInfo: T cell receptor gamma TRG and delta TRD genes in database give access to all TR potential V(D)J recombinations. BMC Bioinformatics 2006, 7, 224. [CrossRef] [PubMed]

10. Pang, D.J.; Neves, J.F.; Sumaria, N.; Pennington, D.J. Understanding the complexity of $\gamma \delta$ T-cell subsets in mouse and human. Immunology 2012, 136, 283-290. [CrossRef] [PubMed]

11. Heilig, J.S.; Tonegawa, S. Diversity of murine gamma genes and expression in fetal and adult T lymphocytes. Nature 1986, 322, 836-840. [CrossRef]

12. LeFranc, M.P.; Forster, A.; Baer, R.; Stinson, M.A.; Rabbitts, T.H. Diversity and rearrangement of the human T cell rearranging gamma genes: Nine germ-line variable genes belonging to two subgroups. Cell 1986, 45, 237-246. [CrossRef]

13. Vantourout, P.; Hayday, A. Six-of-the-best: Unique contributions of $\gamma \delta$ T cells to immunology. Nat. Rev. Immunol. 2013, 13, 88-100. [CrossRef]

14. Patel, S.; Burga, R.A.; Powell, A.B.; Chorvinsky, E.A.; Hoq, N.; McCormack, S.E.; Van Pelt, S.N.; Hanley, P.J.; Cruz, C.R.Y. Beyond CAR T Cells: Other Cell-Based Immunotherapeutic Strategies Against Cancer. Front. Oncol. 2019, 9, 196. [CrossRef]

15. Sebestyen, Z.; Prinz, I.; Déchanet-Merville, J.; Silva-Santos, B.; Kuball, J. Translating gammadelta $(\gamma \delta) \mathrm{T}$ cells and their receptors into cancer cell therapies. Nat. Rev. Drug Discov. 2020, 19, 169-184. [CrossRef] [PubMed] 
16. Silva-Santos, B.; Mensurado, S.; Coffelt, S.B. $\gamma \delta$ T cells: Pleiotropic immune effectors with therapeutic potential in cancer. Nat. Rev. Cancer 2019, 19, 392-404. [CrossRef]

17. Godfrey, D.I.; Le Nours, J.; Andrews, D.M.; Uldrich, A.P.; Rossjohn, J. Unconventional T Cell Targets for Cancer Immunotherapy. Immunity 2018, 48, 453-473. [CrossRef]

18. Castella, B.; Kopecka, J.; Sciancalepore, P.; Mandili, G.; Foglietta, M.; Mitro, N.; Caruso, D.; Novelli, F.; Riganti, C.; Massaia, M. The ATP-binding cassette transporter A1 regulates phosphoantigen release and V $\gamma 9 \mathrm{~V} \delta 2 \mathrm{~T}$ cell activation by dendritic cells. Nat. Commun. 2017, 8, 15663. [CrossRef] [PubMed]

19. Zocchi, M.R.; Costa, D.; Venè, R.; Tosetti, F.; Ferrari, N.; Minghelli, S.; Benelli, R.; Scabini, S.; Romairone, E.; Catellani, S.; et al. Zoledronate can induce colorectal cancer microenvironment expressing BTN3A1 to stimulate effector $\gamma \delta$ T cells with antitumor activity. Oncoimmunology 2017, 6, e1278099. [CrossRef]

20. Blazquez, J.L.; Benyamine, A.; Pasero, C.; Olive, D. New Insights into the Regulation of $\gamma \delta$ T Cells by BTN3A and Other BTN/BTNL in Tumor Immunity. Front. Immunol. 2018, 9, 1601. [CrossRef]

21. Payne, K.K.; Mine, J.A.; Biswas, S.; Chaurio, R.A.; Perales-Puchalt, A.; Anadon, C.M.; Costich, T.L.; Harro, C.M.; Walrath, J.; Ming, Q.; et al. BTN3A1 governs antitumor responses by coordinating $\alpha \beta$ and $\gamma \delta$ T cells. Science 2020, 369, 942-949. [CrossRef]

22. Sawaisorn, P.; Tangchaikeeree, T.; Chan-On, W.; Leepiyasakulchai, C.; Udomsangpetch, R.; Hongeng, S.; Jangpatarapongsa, K. Antigen-Presenting Cell Characteristics of Human $\gamma \delta$ T Lymphocytes in Chronic Myeloid Leukemia. Immunol. Investig. 2019, 48, 11-26. [CrossRef]

23. Holmen Olofsson, G.; Idorn, M.; Carnaz Simões, A.M.; Aehnlich, P.; Skadborg, S.K.; Noessner, E.; Debets, R.; Moser, B.; Met, Ö.; Thor Straten, P. V $\gamma 9$ V 82 T Cells Concurrently Kill Cancer Cells and Cross-Present Tumor Antigens. Front. Immunol. 2021, $12,645131$. [CrossRef]

24. Rampoldi, F.; Ullrich, L.; Prinz, I. Revisiting the Interaction of $\gamma \delta$ T-Cells and B-Cells. Cells 2020, 9, 743. [CrossRef] [PubMed]

25. Di Lorenzo, B.; Simões, A.E.; Caiado, F.; Tieppo, P.; Correia, D.V.; Carvalho, T.; da Silva, M.G.; Déchanet-Merville, J.; Schumacher, T.N.; Prinz, I.; et al. Broad Cytotoxic Targeting of Acute Myeloid Leukemia by Polyclonal Delta One T Cells. Cancer Immunol. Res. 2019, 7, 552-558. [CrossRef] [PubMed]

26. Bonneville, M.; O’Brien, R.L.; Born, W.K. Gammadelta T cell effector functions: A blend of innate programming and acquired plasticity. Nat. Rev. Immunol. 2010, 10, 467-478. [CrossRef] [PubMed]

27. Tawfik, D.; Groth, C.; Gundlach, J.P.; Peipp, M.; Kabelitz, D.; Becker, T.; Oberg, H.H.; Trauzold, A.; Wesch, D. TRAIL-Receptor 4 Modulates $\gamma \delta$ T Cell-Cytotoxicity Toward Cancer Cells. Front. Immunol. 2019, 10, 2044. [CrossRef]

28. Deseke, M.; Prinz, I. Ligand recognition by the $\gamma \delta$ TCR and discrimination between homeostasis and stress conditions. Cell Mol. Immunol. 2020, 17, 914-924. [CrossRef]

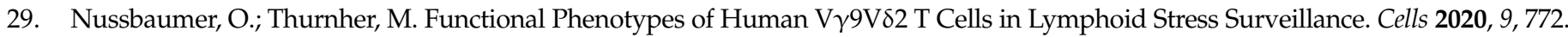
[CrossRef]

30. Maggi, L.; Santarlasci, V.; Capone, M.; Peired, A.; Frosali, F.; Crome, S.Q.; Querci, V.; Fambrini, M.; Liotta, F.; Levings, M.K.; et al. CD161 is a marker of all human IL-17-producing T-cell subsets and is induced by RORC. Eur J. Immunol. 2010, 40, $2174-2181$. [CrossRef]

31. Hunter, S.; Willcox, C.R.; Davey, M.S.; Kasatskaya, S.A.; Jeffery, H.C.; Chudakov, D.M.; Oo, Y.H.; Willcox, B.E. Human liver infiltrating $\gamma \delta$ T cells are composed of clonally expanded circulating and tissue-resident populations. J. Hepatol. 2018, 69, 654-665. [CrossRef]

32. Dieli, F.; Poccia, F.; Lipp, M.; Sireci, G.; Caccamo, N.; Di Sano, C.; Salerno, A. Differentiation of effector/memory Vdelta2 T cells and migratory routes in lymph nodes or inflammatory sites. J. Exp. Med. 2003, 198, 391-397. [CrossRef]

33. Kadekar, D.; Agerholm, R.; Rizk, J.; Neubauer, H.A.; Suske, T.; Maurer, B.; Viñals, M.T.; Comelli, E.M.; Taibi, A.; Moriggl, R.; et al. The neonatal microenvironment programs innate $\gamma \delta \mathrm{T}$ cells through the transcription factor STAT5. J. Clin. Investig. 2020, 130, 2496-2508. [CrossRef]

34. Lopes, N.; McIntyre, C.; Martin, S.; Raverdeau, M.; Sumaria, N.; Kohlgruber, A.C.; Fiala, G.J.; Agudelo, L.Z.; Dyck, L.; Kane, H.; et al. Distinct metabolic programs established in the thymus control effector functions of $\gamma \delta \mathrm{T}$ cell subsets in tumor microenvironments. Nat. Immunol. 2021, 22, 179-192. [CrossRef]

35. Ribeiro, S.T.; Ribot, J.C.; Silva-Santos, B. Five Layers of Receptor Signaling in $\gamma \delta$ T-Cell Differentiation and Activation. Front. Immunol. 2015, 6, 15. [CrossRef] [PubMed]

36. Lee, H.W.; Chung, Y.S.; Kim, T.J. Heterogeneity of Human $\gamma \delta$ T Cells and Their Role in Cancer Immunity. Immune Netw. 2020, 20 , e5. [CrossRef]

37. Chen, X.; Shang, W.; Xu, R.; Wu, M.; Zhang, X.; Huang, P.; Wang, F.; Pan, S. Distribution and functions of $\gamma \delta \mathrm{T}$ cells infiltrated in the ovarian cancer microenvironment. J. Transl. Med. 2019, 17, 144. [CrossRef]

38. Lo Presti, E.; Pizzolato, G.; Corsale, A.M.; Caccamo, N.; Sireci, G.; Dieli, F.; Meraviglia, S. $\gamma \delta$ T Cells and Tumor Microenvironment: From Immunosurveillance to Tumor Evasion. Front. Immunol. 2018, 9, 1395. [CrossRef]

39. Wu, P.; Wu, D.; Ni, C.; Ye, J.; Chen, W.; Hu, G.; Wang, Z.; Wang, C.; Zhang, Z.; Xia, W.; et al. $\gamma \delta T 17$ cells promote the accumulation and expansion of myeloid-derived suppressor cells in human colorectal cancer. Immunity 2014, 40, 785-800. [CrossRef]

40. Sacchi, A.; Tumino, N.; Sabatini, A.; Cimini, E.; Casetti, R.; Bordoni, V.; Grassi, G.; Agrati, C. Myeloid-Derived Suppressor Cells Specifically Suppress IFN- $\gamma$ Production and Antitumor Cytotoxic Activity of V 22 T Cells. Front. Immunol. 2018, 9, 1271. [CrossRef] 
41. Tomogane, M.; Sano, Y.; Shimizu, D.; Shimizu, T.; Miyashita, M.; Toda, Y.; Hosogi, S.; Tanaka, Y.; Kimura, S.; Ashihara, E. Human V $\gamma 9 \mathrm{~V} \delta 2 \mathrm{~T}$ cells exert anti-tumor activity independently of PD-L1 expression in tumor cells. Biochem. Biophys. Res. Commun. 2021, 573, 132-139. [CrossRef]

42. Sureshbabu, S.K.; Chaukar, D.; Chiplunkar, S.V. Hypoxia regulates the differentiation and anti-tumor effector functions of $\gamma \delta \mathrm{T}$ cells in oral cancer. Clin. Exp. Immunol. 2020, 201, 40-57. [CrossRef]

43. Agerholm, R.; Bekiaris, V. Evolved to protect, designed to destroy: IL-17-producing $\gamma \delta \mathrm{T}$ cells in infection, inflammation, and cancer. Eur. J. Immunol. 2021. [CrossRef]

44. Haas, J.D.; Ravens, S.; Düber, S.; Sandrock, I.; Oberdörfer, L.; Kashani, E.; Chennupati, V.; Föhse, L.; Naumann, R.; Weiss, S.; et al. Development of interleukin-17-producing $\gamma \delta \mathrm{T}$ cells is restricted to a functional embryonic wave. Immunity 2012, 37, 48-59. [CrossRef]

45. Buus, T.B.; Ødum, N.; Geisler, C.; Lauritsen, J.P.H. Three distinct developmental pathways for adaptive and two IFN- $\gamma$-producing $\gamma \delta$ T subsets in adult thymus. Nat. Commun. 2017, 8, 1911. [CrossRef]

46. Sandrock, I.; Reinhardt, A.; Ravens, S.; Binz, C.; Wilharm, A.; Martins, J.; Oberdörfer, L.; Tan, L.; Lienenklaus, S.; Zhang, B.; et al. Genetic models reveal origin, persistence and non-redundant functions of IL-17-producing $\gamma \delta \mathrm{T}$ cells. J. Exp. Med. 2018, 215, 3006-3018. [CrossRef]

47. Muñoz-Ruiz, M.; Sumaria, N.; Pennington, D.J.; Silva-Santos, B. Thymic Determinants of $\gamma \delta$ T Cell Differentiation. Trends Immunol. 2017, 38, 336-344. [CrossRef]

48. Yin, Z.; Chen, C.; Szabo, S.J.; Glimcher, L.H.; Ray, A.; Craft, J. T-Bet expression and failure of GATA-3 cross-regulation lead to default production of IFN-gamma by gammadelta T cells. J. Immunol. 2002, 168, 1566-1571. [CrossRef] [PubMed]

49. Sumaria, N.; Grandjean, C.L.; Silva-Santos, B.; Pennington, D.J. Strong TCR $\gamma \delta$ Signaling Prohibits Thymic Development of IL-17A-Secreting $\gamma \delta$ T Cells. Cell Rep. 2017, 19, 2469-2476. [CrossRef]

50. Zarin, P.; In, T.S.; Chen, E.L.; Singh, J.; Wong, G.W.; Mohtashami, M.; Wiest, D.L.; Anderson, M.K.; Zúñiga-Pflücker, J.C. Integration of T-cell receptor, Notch and cytokine signals programs mouse $\gamma \delta \mathrm{T}$-cell effector differentiation. Immunol. Cell Biol. 2018, 96, 994-1007. [CrossRef]

51. Deusch, K.; Lüling, F.; Reich, K.; Classen, M.; Wagner, H.; Pfeffer, K. A major fraction of human intraepithelial lymphocytes simultaneously expresses the gamma/delta $\mathrm{T}$ cell receptor, the CD8 accessory molecule and preferentially uses the V delta 1 gene segment. Eur J. Immunol. 1991, 21, 1053-1059. [CrossRef] [PubMed]

52. Peng, M.Y.; Wang, Z.H.; Yao, C.Y.; Jiang, L.N.; Jin, Q.L.; Wang, J.; Li, B.Q. Interleukin 17-producing gamma delta T cells increased in patients with active pulmonary tuberculosis. Cell Mol. Immunol. 2008, 5, 203-208. [CrossRef] [PubMed]

53. Fenoglio, D.; Poggi, A.; Catellani, S.; Battaglia, F.; Ferrera, A.; Setti, M.; Murdaca, G.; Zocchi, M.R. Vdelta1 T lymphocytes producing IFN-gamma and IL-17 are expanded in HIV-1-infected patients and respond to Candida albicans. Blood 2009, 113, 6611-6618. [CrossRef] [PubMed]

54. Ness-Schwickerath, K.J.; Jin, C.; Morita, C.T. Cytokine requirements for the differentiation and expansion of IL-17A- and IL-22-producing human Vgamma2Vdelta2 T cells. J. Immunol. 2010, 184, 7268-7280. [CrossRef]

55. Caccamo, N.; La Mendola, C.; Orlando, V.; Meraviglia, S.; Todaro, M.; Stassi, G.; Sireci, G.; Fournié, J.J.; Dieli, F. Differentiation, phenotype, and function of interleukin-17-producing human V $\gamma 9 \mathrm{~V} \delta 2$ T cells. Blood 2011, 118, 129-138. [CrossRef] [PubMed]

56. Ryan, P.L.; Sumaria, N.; Holland, C.J.; Bradford, C.M.; Izotova, N.; Grandjean, C.L.; Jawad, A.S.; Bergmeier, L.A.; Pennington, D.J. Heterogeneous yet stable V $\delta 2(+)$ T-cell profiles define distinct cytotoxic effector potentials in healthy human individuals. Proc. Natl. Acad. Sci. USA 2016, 113, 14378-14383. [CrossRef] [PubMed]

57. Tan, L.; Fichtner, A.S.; Bruni, E.; Odak, I.; Sandrock, I.; Bubke, A.; Borchers, A.; Schultze-Florey, C.; Koenecke, C.; Förster, R.; et al. A fetal wave of human type 3 effector $\gamma \delta$ cells with restricted TCR diversity persists into adulthood. Sci. Immunol. 2021, 6, eabf0125. [CrossRef] [PubMed]

58. Giri, S.; Lal, G. Differentiation and functional plasticity of gamma-delta $(\gamma \delta) \mathrm{T}$ cells under homeostatic and disease conditions. Mol. Immunol. 2021, 136, 138-149. [CrossRef]

59. McKenzie, D.R.; Kara, E.E.; Bastow, C.R.; Tyllis, T.S.; Fenix, K.A.; Gregor, C.E.; Wilson, J.J.; Babb, R.; Paton, J.C.; Kallies, A.; et al. IL-17-producing $\gamma \delta$ T cells switch migratory patterns between resting and activated states. Nat. Commun. 2017, 8, 15632. [CrossRef]

60. Casetti, R.; Martino, A. The plasticity of gamma delta T cells: Innate immunity, antigen presentation and new immunotherapy. Cell Mol. Immunol. 2008, 5, 161-170. [CrossRef]

61. Lafont, V.; Sanchez, F.; Laprevotte, E.; Michaud, H.A.; Gros, L.; Eliaou, J.F.; Bonnefoy, N. Plasticity of $\gamma \delta$ T Cells: Impact on the Anti-Tumor Response. Front. Immunol. 2014, 5, 622. [CrossRef] [PubMed]

62. Rezende, R.M.; Lanser, A.J.; Rubino, S.; Kuhn, C.; Skillin, N.; Moreira, T.G.; Liu, S.; Gabriely, G.; David, B.A.; Menezes, G.B.; et al. $\gamma \delta \mathrm{T}$ cells control humoral immune response by inducing $\mathrm{T}$ follicular helper cell differentiation. Nat. Commun. 2018, 9, 3151. [CrossRef] [PubMed]

63. Casetti, R.; Agrati, C.; Wallace, M.; Sacchi, A.; Martini, F.; Martino, A.; Rinaldi, A.; Malkovsky, M. Cutting edge: TGF-beta1 and IL-15 Induce FOXP3+ gammadelta regulatory T cells in the presence of antigen stimulation. J. Immunol. 2009, 183, $3574-3577$. [CrossRef] [PubMed]

64. Park, J.H.; Kim, H.J.; Kim, C.W.; Kim, H.C.; Jung, Y.; Lee, H.S.; Lee, Y.; Ju, Y.S.; Oh, J.E.; Park, S.H.; et al. Tumor hypoxia represses $\gamma \delta \mathrm{T}$ cell-mediated antitumor immunity against brain tumors. Nat. Immunol. 2021, 22, 336-346. [CrossRef] 
65. Li, L.; Cao, B.; Liang, X.; Lu, S.; Luo, H.; Wang, Z.; Wang, S.; Jiang, J.; Lang, J.; Zhu, G. Microenvironmental oxygen pressure orchestrates an anti- and pro-tumoral $\gamma \delta \mathrm{T}$ cell equilibrium via tumor-derived exosomes. Oncogene 2019, 38, 2830-2843. [CrossRef] [PubMed]

66. Siegers, G.M.; Dutta, I.; Lai, R.; Postovit, L.M. Functional Plasticity of Gamma Delta T Cells and Breast Tumor Targets in Hypoxia. Front. Immunol. 2018, 9, 1367. [CrossRef] [PubMed]

67. Douguet, L.; Bod, L.; Lengagne, R.; Labarthe, L.; Kato, M.; Avril, M.F.; Prévost-Blondel, A. Nitric oxide synthase 2 is involved in the pro-tumorigenic potential of $\gamma \delta 17 \mathrm{~T}$ cells in melanoma. Oncoimmunology 2016, 5, e1208878. [CrossRef]

68. Zhao, N.; Dang, H.; Ma, L.; Martin, S.P.; Forgues, M.; Ylaya, K.; Hewitt, S.M.; Wang, X.W. Intratumoral $\gamma \delta$ T-Cell Infiltrates, Chemokine (C-C Motif) Ligand 4/Chemokine (C-C Motif) Ligand 5 Protein Expression and Survival in Patients With Hepatocellular Carcinoma. Hepatology 2021, 73, 1045-1060. [CrossRef] [PubMed]

69. Pietschmann, K.; Beetz, S.; Welte, S.; Martens, I.; Gruen, J.; Oberg, H.H.; Wesch, D.; Kabelitz, D. Toll-like receptor expression and function in subsets of human gammadelta T lymphocytes. Scand. J. Immunol. 2009, 70, 245-255. [CrossRef] [PubMed]

70. Gertner-Dardenne, J.; Bonnafous, C.; Bezombes, C.; Capietto, A.H.; Scaglione, V.; Ingoure, S.; Cendron, D.; Gross, E.; Lepage, J.F.; Quillet-Mary, A.; et al. Bromohydrin pyrophosphate enhances antibody-dependent cell-mediated cytotoxicity induced by therapeutic antibodies. Blood 2009, 113, 4875-4884. [CrossRef]

71. Toutirais, O.; Cabillic, F.; Le Friec, G.; Salot, S.; Loyer, P.; Le Gallo, M.; Desille, M.; de La Pintière, C.T.; Daniel, P.; Bouet, F.; et al. DNAX accessory molecule-1 (CD226) promotes human hepatocellular carcinoma cell lysis by Vgamma9Vdelta2 T cells. Eur. J. Immunol. 2009, 39, 1361-1368. [CrossRef]

72. Sperling, A.I.; Linsley, P.S.; Barrett, T.A.; Bluestone, J.A. CD28-mediated costimulation is necessary for the activation of T cell receptor-gamma delta + T lymphocytes. J. Immunol. 1993, 151, 6043-6050. [PubMed]

73. Stojanovic, A.; Correia, M.P.; Cerwenka, A. The NKG2D/NKG2DL Axis in the Crosstalk Between Lymphoid and Myeloid Cells in Health and Disease. Front. Immunol. 2018, 9, 827. [CrossRef] [PubMed]

74. Wrobel, P.; Shojaei, H.; Schittek, B.; Gieseler, F.; Wollenberg, B.; Kalthoff, H.; Kabelitz, D.; Wesch, D. Lysis of a broad range of epithelial tumour cells by human gamma delta T cells: Involvement of NKG2D ligands and T-cell receptor- versus NKG2Ddependent recognition. Scand. J. Immunol. 2007, 66, 320-328. [CrossRef]

75. Das, H.; Groh, V.; Kuijl, C.; Sugita, M.; Morita, C.T.; Spies, T.; Bukowski, J.F. MICA engagement by human Vgamma2Vdelta2 T cells enhances their antigen-dependent effector function. Immunity 2001, 15, 83-93. [CrossRef]

76. Correia, D.V.; Fogli, M.; Hudspeth, K.; da Silva, M.G.; Mavilio, D.; Silva-Santos, B. Differentiation of human peripheral blood $\mathrm{V} \delta 1+\mathrm{T}$ cells expressing the natural cytotoxicity receptor NKp30 for recognition of lymphoid leukemia cells. Blood 2011, 118, 992-1001. [CrossRef] [PubMed]

77. von Lilienfeld-Toal, M.; Nattermann, J.; Feldmann, G.; Sievers, E.; Frank, S.; Strehl, J.; Schmidt-Wolf, I.G. Activated gammadelta T cells express the natural cytotoxicity receptor natural killer p 44 and show cytotoxic activity against myeloma cells. Clin. Exp. Immunol. 2006, 144, 528-533. [CrossRef] [PubMed]

78. Mikulak, J.; Oriolo, F.; Bruni, E.; Roberto, A.; Colombo, F.S.; Villa, A.; Bosticardo, M.; Bortolomai, I.; Lo Presti, E.; Meraviglia, S.; et al. NKp46-expressing human gut-resident intraepithelial V $\delta 1 \mathrm{~T}$ cell subpopulation exhibits high antitumor activity against colorectal cancer. JCI Insight 2019, 4, 24. [CrossRef] [PubMed]

79. Constant, P.; Davodeau, F.; Peyrat, M.A.; Poquet, Y.; Puzo, G.; Bonneville, M.; Fournié, J.J. Stimulation of human gamma delta T cells by nonpeptidic mycobacterial ligands. Science 1994, 264, 267-270. [CrossRef]

80. Thompson, K.; Roelofs, A.J.; Jauhiainen, M.; Mönkkönen, H.; Mönkkönen, J.; Rogers, M.J. Activation of $\gamma \delta$ T cells by bisphosphonates. Adv. Exp. Med. Biol. 2010, 658, 11-20. [CrossRef]

81. Bukowski, J.F.; Morita, C.T.; Brenner, M.B. Human gamma delta T cells recognize alkylamines derived from microbes, edible plants, and tea: Implications for innate immunity. Immunity 1999, 11, 57-65. [CrossRef]

82. Thompson, K.; Rojas-Navea, J.; Rogers, M.J. Alkylamines cause Vgamma9Vdelta2 T-cell activation and proliferation by inhibiting the mevalonate pathway. Blood 2006, 107, 651-654. [CrossRef] [PubMed]

83. Gober, H.J.; Kistowska, M.; Angman, L.; Jenö, P.; Mori, L.; De Libero, G. Human T cell receptor gammadelta cells recognize endogenous mevalonate metabolites in tumor cells. J. Exp. Med. 2003, 197, 163-168. [CrossRef] [PubMed]

84. Xu, B.; Pizarro, J.C.; Holmes, M.A.; McBeth, C.; Groh, V.; Spies, T.; Strong, R.K. Crystal structure of a gammadelta T-cell receptor specific for the human MHC class I homolog MICA. Proc. Natl. Acad. Sci. USA 2011, 108, 2414-2419. [CrossRef] [PubMed]

85. Laad, A.D.; Thomas, M.L.; Fakih, A.R.; Chiplunkar, S.V. Human gamma delta T cells recognize heat shock protein-60 on oral tumor cells. Int. J. Cancer 1999, 80, 709-714. [CrossRef]

86. Eagle, R.A.; Traherne, J.A.; Hair, J.R.; Jafferji, I.; Trowsdale, J. ULBP6/RAET1L is an additional human NKG2D ligand. Eur. J. Immunol. 2009, 39, 3207-3216. [CrossRef]

87. Eagle, R.A.; Trowsdale, J. Promiscuity and the single receptor: NKG2D. Nat. Rev. Immunol. 2007, 7, 737-744. [CrossRef] [PubMed]

88. Fu, Y.X.; Vollmer, M.; Kalataradi, H.; Heyborne, K.; Reardon, C.; Miles, C.; O’Brien, R.; Born, W. Structural requirements for peptides that stimulate a subset of gamma delta T cells. J. Immunol. 1994, 152, 1578-1588.

89. Uldrich, A.P.; Le Nours, J.; Pellicci, D.G.; Gherardin, N.A.; McPherson, K.G.; Lim, R.T.; Patel, O.; Beddoe, T.; Gras, S.; Rossjohn, J.; et al. CD1d-lipid antigen recognition by the $\gamma \delta$ TCR. Nat. Immunol. 2013, 14, 1137-1145. [CrossRef] [PubMed] 
90. Luoma, A.M.; Castro, C.D.; Mayassi, T.; Bembinster, L.A.; Bai, L.; Picard, D.; Anderson, B.; Scharf, L.; Kung, J.E.; Sibener, L.V.; et al. Crystal structure of V $\delta 1 \mathrm{~T}$ cell receptor in complex with CD1d-sulfatide shows MHC-like recognition of a self-lipid by human $\gamma \delta$ T cells. Immunity 2013, 39, 1032-1042. [CrossRef]

91. Siegers, G.M.; Dhamko, H.; Wang, X.H.; Mathieson, A.M.; Kosaka, Y.; Felizardo, T.C.; Medin, J.A.; Tohda, S.; Schueler, J.; Fisch, P.; et al. Human V $\delta 1 \gamma \delta \mathrm{T}$ cells expanded from peripheral blood exhibit specific cytotoxicity against B-cell chronic lymphocytic leukemia-derived cells. Cytotherapy 2011, 13, 753-764. [CrossRef] [PubMed]

92. Chauvin, C.; Joalland, N.; Perroteau, J.; Jarry, U.; Lafrance, L.; Willem, C.; Retière, C.; Oliver, L.; Gratas, C.; Gautreau-Rolland, L.; et al. NKG2D Controls Natural Reactivity of V $\gamma 9 \mathrm{~V} \delta 2 \mathrm{~T}$ Lymphocytes against Mesenchymal Glioblastoma Cells. Clin. Cancer Res. 2019, 25, 7218-7228. [CrossRef]

93. Nedellec, S.; Sabourin, C.; Bonneville, M.; Scotet, E. NKG2D costimulates human V gamma 9V delta 2 T cell antitumor cytotoxicity through protein kinase $C$ theta-dependent modulation of early TCR-induced calcium and transduction signals. J. Immunol. 2010, 185, 55-63. [CrossRef] [PubMed]

94. O'Neill, K.; Pastar, I.; Tomic-Canic, M.; Strbo, N. Perforins Expression by Cutaneous Gamma Delta T Cells. Front. Immunol. 2020, 11, 1839. [CrossRef] [PubMed]

95. Uchida, R.; Ashihara, E.; Sato, K.; Kimura, S.; Kuroda, J.; Takeuchi, M.; Kawata, E.; Taniguchi, K.; Okamoto, M.; Shimura, K.; et al. Gamma delta T cells kill myeloma cells by sensing mevalonate metabolites and ICAM-1 molecules on cell surface. Biochem. Biophys. Res. Commun. 2007, 354, 613-618. [CrossRef] [PubMed]

96. Harly, C.; Guillaume, Y.; Nedellec, S.; Peigné, C.M.; Mönkkönen, H.; Mönkkönen, J.; Li, J.; Kuball, J.; Adams, E.J.; Netzer, S.; et al. Key implication of CD277/butyrophilin-3 (BTN3A) in cellular stress sensing by a major human $\gamma \delta$ T-cell subset. Blood 2012, 120, 2269-2279. [CrossRef] [PubMed]

97. Rigau, M.; Ostrouska, S.; Fulford, T.S.; Johnson, D.N.; Woods, K.; Ruan, Z.; McWilliam, H.E.G.; Hudson, C.; Tutuka, C.; Wheatley, A.K.; et al. Butyrophilin 2A1 is essential for phosphoantigen reactivity by $\gamma \delta \mathrm{T}$ cells. Science 2020, 367, eaay5516. [CrossRef] [PubMed]

98. Sandstrom, A.; Peigné, C.-M.; Léger, A.; Crooks, J.E.; Konczak, F.; Gesnel, M.-C.; Breathnach, R.; Bonneville, M.; Scotet, E.; Adams, E.J. The intracellular B30.2 domain of butyrophilin 3A1 binds phosphoantigens to mediate activation of human V $\gamma 9 \mathrm{~V} \delta 2 \mathrm{~T}$ cells. Immunity 2014, 40, 490-500. [CrossRef] [PubMed]

99. Nussbaumer, O.; Koslowski, M. The emerging role of $\gamma \delta$ T cells in cancer immunotherapy. Immuno-Oncol. Technol. 2019, 1, 3-10. [CrossRef]

100. Vavassori, S.; Kumar, A.; Wan, G.S.; Ramanjaneyulu, G.S.; Cavallari, M.; El Daker, S.; Beddoe, T.; Theodossis, A.; Williams, N.K.; Gostick, E.; et al. Butyrophilin 3A1 binds phosphorylated antigens and stimulates human $\gamma \delta \mathrm{T}$ cells. Nat. Immunol. 2013, 14, 908-916. [CrossRef]

101. Godfrey, D.I.; Uldrich, A.P.; McCluskey, J.; Rossjohn, J.; Moody, D.B. The burgeoning family of unconventional T cells. Nat. Immunol. 2015, 16, 1114-1123. [CrossRef] [PubMed]

102. Todaro, M.; D'Asaro, M.; Caccamo, N.; Iovino, F.; Francipane, M.G.; Meraviglia, S.; Orlando, V.; La Mendola, C.; Gulotta, G.; Salerno, A.; et al. Efficient killing of human colon cancer stem cells by gammadelta T lymphocytes. J. Immunol. 2009, 182, 7287-7296. [CrossRef] [PubMed]

103. Xiang, Z.; Liu, Y.; Zheng, J.; Liu, M.; Lv, A.; Gao, Y.; Hu, H.; Lam, K.T.; Chan, G.C.; Yang, Y.; et al. Targeted activation of human V $\gamma 9$ V $82-T$ cells controls epstein-barr virus-induced B cell lymphoproliferative disease. Cancer Cell 2014, 26, 565-576. [CrossRef] [PubMed]

104. Braza, M.S.; Klein, B.; Fiol, G.; Rossi, J.F. $\gamma \delta$ T-cell killing of primary follicular lymphoma cells is dramatically potentiated by GA101, a type II glycoengineered anti-CD20 monoclonal antibody. Haematologica 2011, 96, 400-407. [CrossRef] [PubMed]

105. Mizoguchi, A.; Mizoguchi, E.; de Jong, Y.P.; Takedatsu, H.; Preffer, F.I.; Terhorst, C.; Bhan, A.K. Role of the CD5 molecule on TCR gammadelta T cell-mediated immune functions: Development of germinal centers and chronic intestinal inflammation. Int. Immunol. 2003, 15, 97-108. [CrossRef]

106. Huang, Y.; Getahun, A.; Heiser, R.A.; Detanico, T.O.; Aviszus, K.; Kirchenbaum, G.A.; Casper, T.L.; Huang, C.; Aydintug, M.K.; Carding, S.R.; et al. $\gamma \delta$ T Cells Shape Preimmune Peripheral B Cell Populations. J. Immunol. 2016, 196, 217-231. [CrossRef] [PubMed]

107. Caccamo, N.; Battistini, L.; Bonneville, M.; Poccia, F.; Fournié, J.J.; Meraviglia, S.; Borsellino, G.; Kroczek, R.A.; La Mendola, C.; Scotet, E.; et al. CXCR5 identifies a subset of Vgamma9Vdelta2 T cells which secrete IL-4 and IL-10 and help B cells for antibody production. J. Immunol. 2006, 177, 5290-5295. [CrossRef]

108. Bansal, R.R.; Mackay, C.R.; Moser, B.; Eberl, M. IL-21 enhances the potential of human $\gamma \delta$ T cells to provide B-cell help. Eur. J. Immunol. 2012, 42, 110-119. [CrossRef] [PubMed]

109. Petrasca, A.; Melo, A.M.; Breen, E.P.; Doherty, D.G. Human V $\delta 3(+) \gamma \delta$ T cells induce maturation and IgM secretion by B cells. Immunol. Lett. 2018, 196, 126-134. [CrossRef]

110. Brandes, M.; Willimann, K.; Moser, B. Professional antigen-presentation function by human gammadelta T Cells. Science 2005, 309, 264-268. [CrossRef] [PubMed]

111. Gruenbacher, G.; Thurnher, M. Mevalonate metabolism governs cancer immune surveillance. OncoImmunology 2017,6 , e1342917. [CrossRef] [PubMed] 
112. Muto, M.; Baghdadi, M.; Maekawa, R.; Wada, H.; Seino, K. Myeloid molecular characteristics of human $\gamma \delta$ T cells support their acquisition of tumor antigen-presenting capacity. Cancer Immunol. Immunother. 2015, 64, 941-949. [CrossRef] [PubMed]

113. Khan, M.W.A.; Curbishley, S.M.; Chen, H.-C.; Thomas, A.D.; Pircher, H.; Mavilio, D.; Steven, N.M.; Eberl, M.; Moser, B. Expanded Human Blood-Derived $\gamma \delta$ T Cells Display Potent Antigen-Presentation Functions. Front. Immunol. 2014, 5, 344. [CrossRef] [PubMed]

114. Jouen-Beades, F.; Paris, E.; Dieulois, C.; Lemeland, J.F.; Barre-Dezelus, V.; Marret, S.; Humbert, G.; Leroy, J.; Tron, F. In vivo and in vitro activation and expansion of gammadelta T cells during Listeria monocytogenes infection in humans. Infect. Immunol. 1997, 65, 4267-4272. [CrossRef]

115. Devilder, M.C.; Maillet, S.; Bouyge-Moreau, I.; Donnadieu, E.; Bonneville, M.; Scotet, E. Potentiation of antigen-stimulated V gamma 9V delta $2 \mathrm{~T}$ cell cytokine production by immature dendritic cells (DC) and reciprocal effect on DC maturation. J. Immunol. 2006, 176, 1386-1393. [CrossRef]

116. Münz, C.; Steinman, R.M.; Fujii, S. Dendritic cell maturation by innate lymphocytes: Coordinated stimulation of innate and adaptive immunity. J. Exp. Med. 2005, 202, 203-207. [CrossRef] [PubMed]

117. Leslie, D.S.; Vincent, M.S.; Spada, F.M.; Das, H.; Sugita, M.; Morita, C.T.; Brenner, M.B. CD1-mediated gamma/delta T cell maturation of dendritic cells. J. Exp. Med. 2002, 196, 1575-1584. [CrossRef]

118. Conti, L.; Casetti, R.; Cardone, M.; Varano, B.; Martino, A.; Belardelli, F.; Poccia, F.; Gessani, S. Reciprocal activating interaction between dendritic cells and pamidronate-stimulated gammadelta T cells: Role of CD86 and inflammatory cytokines. J. Immunol. 2005, 174, 252-260. [CrossRef]

119. Girard, P.; Ponsard, B.; Charles, J.; Chaperot, L.; Aspord, C. Potent Bidirectional Cross-Talk Between Plasmacytoid Dendritic Cells and $\gamma \delta$ T Cells Through BTN3A, Type I/II IFNs and Immune Checkpoints. Front. Immunol. 2020, 11, 11. [CrossRef] [PubMed]

120. Mangan, B.A.; Dunne, M.R.; O’Reilly, V.P.; Dunne, P.J.; Exley, M.A.; O’Shea, D.; Scotet, E.; Hogan, A.E.; Doherty, D.G. Cutting edge: CD1d restriction and Th1/Th2/Th17 cytokine secretion by human V83 T cells. J. Immunol. 2013, 191, 30-34. [CrossRef]

121. Wang, J.; Lin, C.; Li, H.; Li, R.; Wu, Y.; Liu, H.; Zhang, H.; He, H.; Zhang, W.; Xu, J. Tumor-infiltrating $\gamma \delta T$ cells predict prognosis and adjuvant chemotherapeutic benefit in patients with gastric cancer. Oncoimmunology 2017, 6, e1353858. [CrossRef] [PubMed]

122. Jiang, Y.; Tang, F.; Li, Z.; Cui, L.; He, W. Critical role of $\gamma 4$ chain in the expression of functional V $\gamma 4 \mathrm{~V} \delta 1 \mathrm{~T}$ cell receptor of gastric tumour-infiltrating $\gamma \delta$ T lymphocytes. Scand. J. Immunol. 2012, 75, 102-108. [CrossRef]

123. Foord, E.; Arruda, L.C.M.; Gaballa, A.; Klynning, C.; Uhlin, M. Characterization of ascites- and tumor-infiltrating $\gamma \delta \mathrm{T}$ cells reveals distinct repertoires and a beneficial role in ovarian cancer. Sci. Transl. Med. 2021, 13, 13. [CrossRef] [PubMed]

124. Andreu-Ballester, J.C.; Galindo-Regal, L.; Hidalgo-Coloma, J.; Cuéllar, C.; García-Ballesteros, C.; Hurtado, C.; Uribe, N.; Del Carmen Martín, M.; Jiménez, A.I.; López-Chuliá, F.; et al. Differences in circulating $\gamma \delta \mathrm{T}$ cells in patients with primary colon cancer and relation with prognostic factors. PLoS ONE 2020, 15, e0243545. [CrossRef]

125. Narayanan, S.; Kawaguchi, T.; Yan, L.; Peng, X.; Qi, Q.; Takabe, K. Cytolytic Activity Score to Assess Anticancer Immunity in Colorectal Cancer. Ann. Surg. Oncol. 2018, 25, 2323-2331. [CrossRef] [PubMed]

126. Zhang, S.; Zhang, E.; Long, J.; Hu, Z.; Peng, J.; Liu, L.; Tang, F.; Li, L.; Ouyang, Y.; Zeng, Z. Immune infiltration in renal cell carcinoma. Cancer Sci. 2019, 110, 1564-1572. [CrossRef] [PubMed]

127. Lee, H.W.; Park, C.; Joung, J.G.; Kang, M.; Chung, Y.S.; Oh, W.J.; Yeom, S.Y.; Park, W.Y.; Kim, T.J.; Seo, S.I. Renal Cell CarcinomaInfiltrating CD3(low) V $\gamma 9 \mathrm{~V} \delta 1 \mathrm{~T}$ Cells Represent Potentially Novel Anti-Tumor Immune Players. Curr. Issues Mol. Biol. 2021, 43, 226-239. [CrossRef] [PubMed]

128. Bryant, N.L.; Suarez-Cuervo, C.; Gillespie, G.Y.; Markert, J.M.; Nabors, L.B.; Meleth, S.; Lopez, R.D.; Lamb, L.S., Jr. Characterization and immunotherapeutic potential of gammadelta T-cells in patients with glioblastoma. Neuro. Oncol. 2009, 11, 357-367. [CrossRef] [PubMed]

129. Boissière-Michot, F.; Chabab, G.; Mollevi, C.; Guiu, S.; Lopez-Crapez, E.; Ramos, J.; Bonnefoy, N.; Lafont, V.; Jacot, W. Clinicopathological Correlates of $\gamma \delta$ T Cell Infiltration in Triple-Negative Breast Cancer. Cancers 2021, 13, 765. [CrossRef] [PubMed]

130. Hidalgo, J.V.; Bronsert, P.; Orlowska-Volk, M.; Díaz, L.B.; Stickeler, E.; Werner, M.; Schmitt-Graeff, A.; Kayser, G.; Malkovsky, M.; Fisch, P. Histological Analysis of $\gamma \delta$ T Lymphocytes Infiltrating Human Triple-Negative Breast Carcinomas. Front. Immunol. 2014, 5, 632. [CrossRef] [PubMed]

131. Wu, Y.; Kyle-Cezar, F.; Woolf, R.T.; Naceur-Lombardelli, C.; Owen, J.; Biswas, D.; Lorenc, A.; Vantourout, P.; Gazinska, P.; Grigoriadis, A.; et al. An innate-like V $\delta 1(+) \gamma \delta \mathrm{T}$ cell compartment in the human breast is associated with remission in triplenegative breast cancer. Sci. Transl. Med. 2019, 11, eaax9364. [CrossRef] [PubMed]

132. Lo Presti, E.; Mocciaro, F.; Mitri, R.D.; Corsale, A.M.; Di Simone, M.; Vieni, S.; Scibetta, N.; Unti, E.; Dieli, F.; Meraviglia, S. Analysis of colon-infiltrating $\gamma \delta \mathrm{T}$ cells in chronic inflammatory bowel disease and in colitis-associated cancer. J. Leukoc. Biol. 2020, 108, 749-760. [CrossRef] [PubMed]

133. Chabab, G.; Barjon, C.; Abdellaoui, N.; Salvador-Prince, L.; Dejou, C.; Michaud, H.A.; Boissière-Michot, F.; Lopez-Crapez, E.; Jacot, W.; Pourquier, D.; et al. Identification of a regulatory V $\delta 1$ gamma delta T cell subpopulation expressing CD73 in human breast cancer. J. Leukoc. Biol. 2020, 107, 1057-1067. [CrossRef] [PubMed]

134. Coffelt, S.B.; Kersten, K.; Doornebal, C.W.; Weiden, J.; Vrijland, K.; Hau, C.S.; Verstegen, N.J.M.; Ciampricotti, M.; Hawinkels, L.; Jonkers, J.; et al. IL-17-producing $\gamma \delta \mathrm{T}$ cells and neutrophils conspire to promote breast cancer metastasis. Nature 2015, 522, 345-348. [CrossRef] 
135. Lopes, N.; Silva-Santos, B. Functional and metabolic dichotomy of murine $\gamma \delta$ T cell subsets in cancer immunity. Eur. J. Immunol. 2021, 51, 17-26. [CrossRef]

136. Lo Presti, E.; Toia, F.; Oieni, S.; Buccheri, S.; Turdo, A.; Mangiapane, L.R.; Campisi, G.; Caputo, V.; Todaro, M.; Stassi, G.; et al. Squamous Cell Tumors Recruit $\gamma \delta$ T Cells Producing either IL17 or IFN $\gamma$ Depending on the Tumor Stage. Cancer Immunol. Res. 2017, 5, 397-407. [CrossRef]

137. Wilhelm, M.; Kunzmann, V.; Eckstein, S.; Reimer, P.; Weissinger, F.; Ruediger, T.; Tony, H.P. Gammadelta T cells for immune therapy of patients with lymphoid malignancies. Blood 2003, 102, 200-206. [CrossRef]

138. Kunzmann, V.; Smetak, M.; Kimmel, B.; Weigang-Koehler, K.; Goebeler, M.; Birkmann, J.; Becker, J.; Schmidt-Wolf, I.G.; Einsele, H.; Wilhelm, M. Tumor-promoting versus tumor-antagonizing roles of $\gamma \delta \mathrm{T}$ cells in cancer immunotherapy: Results from a prospective phase I/II trial. J. Immunother. 2012, 35, 205-213. [CrossRef]

139. Castella, B.; Vitale, C.; Coscia, M.; Massaia, M. V $\gamma 9 \mathrm{~V} \delta 2$ T cell-based immunotherapy in hematological malignancies: From bench to bedside. Cell Mol. Life Sci. 2011, 68, 2419-2432. [CrossRef]

140. Dolstra, H.; Fredrix, H.; van der Meer, A.; de Witte, T.; Figdor, C.; van de Wiel-van Kemenade, E. TCR gamma delta cytotoxic T lymphocytes expressing the killer cell-inhibitory receptor p58.2 (CD158b) selectively lyse acute myeloid leukemia cells. Bone Marrow Transplant. 2001, 27, 1087-1093. [CrossRef]

141. Gertner-Dardenne, J.; Castellano, R.; Mamessier, E.; Garbit, S.; Kochbati, E.; Etienne, A.; Charbonnier, A.; Collette, Y.; Vey, N.; Olive, D. Human V $\gamma 9 \mathrm{~V} \delta 2 \mathrm{~T}$ cells specifically recognize and kill acute myeloid leukemic blasts. J. Immunol. 2012, 188, 4701-4708. [CrossRef]

142. Gomes, A.Q.; Correia, D.V.; Grosso, A.R.; Lança, T.; Ferreira, C.; Lacerda, J.F.; Barata, J.T.; Silva, M.G.; Silva-Santos, B. Identification of a panel of ten cell surface protein antigens associated with immunotargeting of leukemias and lymphomas by peripheral blood gammadelta T cells. Haematologica 2010, 95, 1397-1404. [CrossRef] [PubMed]

143. D'Asaro, M.; La Mendola, C.; Di Liberto, D.; Orlando, V.; Todaro, M.; Spina, M.; Guggino, G.; Meraviglia, S.; Caccamo, N.; Messina, A.; et al. V gamma 9V delta $2 \mathrm{~T}$ lymphocytes efficiently recognize and kill zoledronate-sensitized, imatinib-sensitive, and imatinib-resistant chronic myelogenous leukemia cells. J. Immunol. 2010, 184, 3260-3268. [CrossRef]

144. Knight, A.; Mackinnon, S.; Lowdell, M.W. Human Vdelta1 gamma-delta T cells exert potent specific cytotoxicity against primary multiple myeloma cells. Cytotherapy 2012, 14, 1110-1118. [CrossRef] [PubMed]

145. Kunzmann, V.; Bauer, E.; Feurle, J.; Weissinger, F.; Tony, H.P.; Wilhelm, M. Stimulation of gammadelta T cells by aminobisphosphonates and induction of antiplasma cell activity in multiple myeloma. Blood 2000, 96, 384-392. [CrossRef]

146. Almeida, A.R.; Correia, D.V.; Fernandes-Platzgummer, A.; da Silva, C.L.; da Silva, M.G.; Anjos, D.R.; Silva-Santos, B. Delta One T Cells for Immunotherapy of Chronic Lymphocytic Leukemia: Clinical-Grade Expansion/Differentiation and Preclinical Proof of Concept. Clin. Cancer Res. 2016, 22, 5795-5804. [CrossRef] [PubMed]

147. Sicard, H.; Al Saati, T.; Delsol, G.; Fournié, J.J. Synthetic phosphoantigens enhance human Vgamma9Vdelta2 T lymphocytes killing of non-Hodgkin's B lymphoma. Mol. Med. 2001, 7, 711-722. [CrossRef]

148. Street, S.E.; Hayakawa, Y.; Zhan, Y.; Lew, A.M.; MacGregor, D.; Jamieson, A.M.; Diefenbach, A.; Yagita, H.; Godfrey, D.I.; Smyth, M.J. Innate immune surveillance of spontaneous B cell lymphomas by natural killer cells and gammadelta T cells. J. Exp. Med. 2004, 199, 879-884. [CrossRef]

149. Zumwalde, N.A.; Sharma, A.; Xu, X.; Ma, S.; Schneider, C.L.; Romero-Masters, J.C.; Hudson, A.W.; Gendron-Fitzpatrick, A.; Kenney, S.C.; Gumperz, J.E. Adoptively transferred V $\gamma 9 \mathrm{~V} \delta 2 \mathrm{~T}$ cells show potent antitumor effects in a preclinical B cell lymphomagenesis model. JCI Insight 2017, 2, 13. [CrossRef]

150. Gundermann, S.; Klinker, E.; Kimmel, B.; Flierl, U.; Wilhelm, M.; Einsele, H.; Kunzmann, V. A comprehensive analysis of primary acute myeloid leukemia identifies biomarkers predicting susceptibility to human allogeneic V $\gamma 9 \mathrm{~V} \delta 2 \mathrm{~T}$ cells. J. Immunother. 2014, 37, 321-330. [CrossRef]

151. Catellani, S.; Poggi, A.; Bruzzone, A.; Dadati, P.; Ravetti, J.L.; Gobbi, M.; Zocchi, M.R. Expansion of Vdelta1 T lymphocytes producing IL-4 in low-grade non-Hodgkin lymphomas expressing UL-16-binding proteins. Blood 2007, 109, 2078-2085. [CrossRef] [PubMed]

152. Federmann, B.; Bornhauser, M.; Meisner, C.; Kordelas, L.; Beelen, D.W.; Stuhler, G.; Stelljes, M.; Schwerdtfeger, R.; Christopeit, M.; Behre, G.; et al. Haploidentical allogeneic hematopoietic cell transplantation in adults using CD3/CD19 depletion and reduced intensity conditioning: A phase II study. Haematologica 2012, 97, 1523-1531. [CrossRef]

153. Barfield, R.C.; Otto, M.; Houston, J.; Holladay, M.; Geiger, T.; Martin, J.; Leimig, T.; Gordon, P.; Chen, X.; Handgretinger, R. A one-step large-scale method for T- and B-cell depletion of mobilized PBSC for allogeneic transplantation. Cytotherapy 2004, 6, 1-6. [CrossRef] [PubMed]

154. Li Pira, G.; Malaspina, D.; Girolami, E.; Biagini, S.; Cicchetti, E.; Conflitti, G.; Broglia, M.; Ceccarelli, S.; Lazzaro, S.; Pagliara, D.; et al. Selective Depletion of $\alpha \beta$ T Cells and B Cells for Human Leukocyte Antigen-Haploidentical Hematopoietic Stem Cell Transplantation. A Three-Year Follow-Up of Procedure Efficiency. Biol Blood Marrow Transplant. 2016, 22, 2056-2064. [CrossRef]

155. Locatelli, F.; Merli, P.; Pagliara, D.; Li Pira, G.; Falco, M.; Pende, D.; Rondelli, R.; Lucarelli, B.; Brescia, L.P.; Masetti, R.; et al. Outcome of children with acute leukemia given HLA-haploidentical HSCT after $\alpha \beta$ T-cell and B-cell depletion. Blood 2017, 130, 677-685. [CrossRef] 
156. Airoldi, I.; Bertaina, A.; Prigione, I.; Zorzoli, A.; Pagliara, D.; Cocco, C.; Meazza, R.; Loiacono, F.; Lucarelli, B.; Bernardo, M.E.; et al. $\gamma \delta$ T-cell reconstitution after HLA-haploidentical hematopoietic transplantation depleted of TCR- $\alpha \beta+/ C D 19+$ lymphocytes. Blood 2015, 125, 2349-2358. [CrossRef]

157. Godder, K.T.; Henslee-Downey, P.J.; Mehta, J.; Park, B.S.; Chiang, K.Y.; Abhyankar, S.; Lamb, L.S. Long term disease-free survival in acute leukemia patients recovering with increased gammadelta $\mathrm{T}$ cells after partially mismatched related donor bone marrow transplantation. Bone Marrow Transplant. 2007, 39, 751-757. [CrossRef] [PubMed]

158. Ho, C.M.; McCarthy, P.L.; Wallace, P.K.; Zhang, Y.; Fora, A.; Mellors, P.; Tario, J.D.; McCarthy, B.L.S.; Chen, G.L.; Holstein, S.A.; et al. Immune signatures associated with improved progression-free and overall survival for myeloma patients treated with AHSCT. Blood Adv. 2017, 1, 1056-1066. [CrossRef] [PubMed]

159. Klyuchnikov, E.; Badbaran, A.; Massoud, R.; Fritsche-Friedland, U.; Janson, D.; Ayuk, F.; Wolschke, C.; Bacher, U.; Kröger, N. Enhanced Immune Reconstitution of $\gamma \delta$ T Cells after Allogeneic Stem Cell Transplantation Overcomes the Negative Impact of Pretransplantation Minimal Residual Disease-Positive Status in Patients with Acute Myelogenous Leukemia. Transplant. Cell Ther. 2021, 27, 841-850. [CrossRef]

160. Lança, T.; Correia, D.V.; Moita, C.F.; Raquel, H.; Neves-Costa, A.; Ferreira, C.; Ramalho, J.S.; Barata, J.T.; Moita, L.F.; Gomes, A.Q.; et al. The MHC class Ib protein ULBP1 is a nonredundant determinant of leukemia/lymphoma susceptibility to gammadelta T-cell cytotoxicity. Blood 2010, 115, 2407-2411. [CrossRef]

161. Paczulla, A.M.; Rothfelder, K.; Raffel, S.; Konantz, M.; Steinbacher, J.; Wang, H.; Tandler, C.; Mbarga, M.; Schaefer, T.; Falcone, M.; et al. Absence of NKG2D ligands defines leukaemia stem cells and mediates their immune evasion. Nature 2019, 572, 254-259. [CrossRef] [PubMed]

162. Wakita, D.; Sumida, K.; Iwakura, Y.; Nishikawa, H.; Ohkuri, T.; Chamoto, K.; Kitamura, H.; Nishimura, T. Tumor-infiltrating IL-17-producing gammadelta T cells support the progression of tumor by promoting angiogenesis. Eur. J. Immunol. 2010, 40, 1927-1937. [CrossRef]

163. Kabelitz, D.; Serrano, R.; Kouakanou, L.; Peters, C.; Kalyan, S. Cancer immunotherapy with $\gamma \delta$ T cells: Many paths ahead of us. Cell Mol. Immunol. 2020, 17, 925-939. [CrossRef] [PubMed]

164. Park, J.H.; Lee, H.K. Function of $\gamma \delta$ T cells in tumor immunology and their application to cancer therapy. Exp. Mol. Med. 2021, 53, 318-327. [CrossRef]

165. Hoeres, T.; Smetak, M.; Pretscher, D.; Wilhelm, M. Improving the Efficiency of V $\gamma 9$ V $\delta 2$ T-Cell Immunotherapy in Cancer. Front. Immunol. 2018, 9, 800. [CrossRef] [PubMed]

166. De Weerdt, I.; Hofland, T.; Lameris, R.; Endstra, S.; Jongejan, A.; Moerland, P.D.; de Bruin, R.C.G.; Remmerswaal, E.B.M.; Ten Berge, I.J.M.; Liu, N.; et al. Improving CLL V $\gamma 9$ V $82-T$-cell fitness for cellular therapy by ex vivo activation and ibrutinib. Blood 2018, 132, 2260-2272. [CrossRef] [PubMed]

167. Argentati, K.; Re, F.; Serresi, S.; Tucci, M.G.; Bartozzi, B.; Bernardini, G.; Provinciali, M. Reduced number and impaired function of circulating gamma delta T cells in patients with cutaneous primary melanoma. J. Investig. Dermatol. 2003, 120, 829-834. [CrossRef] [PubMed]

168. Kabelitz, D.; Pechhold, K.; Bender, A.; Wesselborg, S.; Wesch, D.; Friese, K.; Janssen, O. Activation and activation-driven death of human gamma/delta T cells. Immunol. Rev. 1991, 120, 71-88. [CrossRef] [PubMed]

169. Siegers, G.M.; Lamb, L.S., Jr. Cytotoxic and regulatory properties of circulating V $\delta 1+\gamma \delta$ T cells: A new player on the cell therapy field? Mol. Ther. 2014, 22, 1416-1422. [CrossRef]

170. Alves, J.J.P.; De Medeiros Fernandes, T.A.A.; De Araújo, J.M.G.; Cobucci, R.N.O.; Lanza, D.C.F.; Bezerra, F.L.; Andrade, V.S.; Fernandes, J.V. Th17 response in patients with cervical cancer. Oncol. Lett. 2018, 16, 6215-6227. [CrossRef]

171. Chen, X.; Zhang, X.; Xu, R.; Shang, W.; Ming, W.; Wang, F.; Wang, J. Implication of IL-17 producing $-\alpha \beta T$ and $\gamma \delta T$ cells in patients with ovarian cancer. Hum. Immunol. 2020, 81, 244-248. [CrossRef]

172. Ma, S.; Cheng, Q.; Cai, Y.; Gong, H.; Wu, Y.; Yu, X.; Shi, L.; Wu, D.; Dong, C.; Liu, H. IL-17A produced by $\gamma \delta \mathrm{T}$ cells promotes tumor growth in hepatocellular carcinoma. Cancer Res. 2014, 74, 1969-1982. [CrossRef] [PubMed]

173. Patil, R.S.; Shah, S.U.; Shrikhande, S.V.; Goel, M.; Dikshit, R.P.; Chiplunkar, S.V. IL17 producing $\gamma \delta T$ cells induce angiogenesis and are associated with poor survival in gallbladder cancer patients. Int. J. Cancer 2016, 139, 869-881. [CrossRef]

174. Carmi, Y.; Rinott, G.; Dotan, S.; Elkabets, M.; Rider, P.; Voronov, E.; Apte, R.N. Microenvironment-derived IL-1 and IL-17 interact in the control of lung metastasis. J. Immunol. 2011, 186, 3462-3471. [CrossRef]

175. Jin, C.; Lagoudas, G.K.; Zhao, C.; Bullman, S.; Bhutkar, A.; Hu, B.; Ameh, S.; Sandel, D.; Liang, X.S.; Mazzilli, S.; et al. Commensal Microbiota Promote Lung Cancer Development via $\gamma \delta$ T Cells. Cell 2019, 176, 998-1013.e16. [CrossRef]

176. Zhang, H.; Chai, W.; Yang, W.; Han, W.; Mou, W.; Xi, Y.; Chen, X.; Wang, H.; Wang, W.; Qin, H.; et al. The increased IL17-producing $\gamma \delta \mathrm{T}$ cells promote tumor cell proliferation and migration in neuroblastoma. Clin. Immunol. 2020, $211,108343$. [CrossRef]

177. Peng, G.; Wang, H.Y.; Peng, W.; Kiniwa, Y.; Seo, K.H.; Wang, R.F. Tumor-infiltrating gammadelta T cells suppress T and dendritic cell function via mechanisms controlled by a unique toll-like receptor signaling pathway. Immunity 2007, 27, 334-348. [CrossRef] [PubMed]

178. Kang, N.; Tang, L.; Li, X.; Wu, D.; Li, W.; Chen, X.; Cui, L.; Ba, D.; He, W. Identification and characterization of Foxp3(+) gammadelta T cells in mouse and human. Immunol. Lett. 2009, 125, 105-113. [CrossRef] 
179. Wesch, D.; Peters, C.; Siegers, G.M. Human gamma delta T regulatory cells in cancer: Fact or fiction? Front. Immunol. 2014, 5, 598. [CrossRef] [PubMed]

180. Hua, F.; Kang, N.; Gao, Y.A.; Cui, L.X.; Ba, D.N.; He, W. Potential regulatory role of in vitro-expanded V $\delta 1$ T cells from human peripheral blood. Immunol. Res. 2013, 56, 172-180. [CrossRef]

181. Landskron, G.; De la Fuente, M.; Thuwajit, P.; Thuwajit, C.; Hermoso, M.A. Chronic inflammation and cytokines in the tumor microenvironment. J. Immunol. Res. 2014, 2014, 149185. [CrossRef]

182. Schlecker, E.; Stojanovic, A.; Eisen, C.; Quack, C.; Falk, C.S.; Umansky, V.; Cerwenka, A. Tumor-infiltrating monocytic myeloidderived suppressor cells mediate CCR5-dependent recruitment of regulatory T cells favoring tumor growth. J. Immunol. 2012, 189, 5602-5611. [CrossRef]

183. Van Hede, D.; Polese, B.; Humblet, C.; Wilharm, A.; Renoux, V.; Dortu, E.; de Leval, L.; Delvenne, P.; Desmet, C.J.; Bureau, F.; et al. Human papillomavirus oncoproteins induce a reorganization of epithelial-associated $\gamma \delta \mathrm{T}$ cells promoting tumor formation. Proc. Natl. Acad. Sci. USA 2017, 114, E9056-E9065. [CrossRef]

184. Rei, M.; Gonçalves-Sousa, N.; Lança, T.; Thompson, R.G.; Mensurado, S.; Balkwill, F.R.; Kulbe, H.; Pennington, D.J.; Silva-Santos, B. Murine CD27(-) $\mathrm{V} \gamma 6(+) \gamma \delta \mathrm{T}$ cells producing IL-17A promote ovarian cancer growth via mobilization of protumor small peritoneal macrophages. Proc. Natl. Acad. Sci. USA 2014, 111, 3562-3570. [CrossRef]

185. Fischer, K.; Hoffmann, P.; Voelkl, S.; Meidenbauer, N.; Ammer, J.; Edinger, M.; Gottfried, E.; Schwarz, S.; Rothe, G.; Hoves, S.; et al. Inhibitory effect of tumor cell-derived lactic acid on human T cells. Blood 2007, 109, 3812-3819. [CrossRef]

186. Chang, C.H.; Qiu, J.; O’Sullivan, D.; Buck, M.D.; Noguchi, T.; Curtis, J.D.; Chen, Q.; Gindin, M.; Gubin, M.M.; van der Windt, G.J.; et al. Metabolic Competition in the Tumor Microenvironment Is a Driver of Cancer Progression. Cell 2015, 162, 1229-1241. [CrossRef]

187. Blank, C.; Brown, I.; Marks, R.; Nishimura, H.; Honjo, T.; Gajewski, T.F. Absence of programmed death receptor 1 alters thymic development and enhances generation of CD4/CD8 double-negative TCR-transgenic T cells. J. Immunol. 2003, 171, 4574-4581. [CrossRef]

188. Chen, S.; Crabill, G.A.; Pritchard, T.S.; McMiller, T.L.; Wei, P.; Pardoll, D.M.; Pan, F.; Topalian, S.L. Mechanisms regulating PD-L1 expression on tumor and immune cells. J. Immunother. Cancer 2019, 7, 305. [CrossRef] [PubMed]

189. Wu, K.; Feng, J.; Xiu, Y.; Li, Z.; Lin, Z.; Zhao, H.; Zeng, H.; Xia, W.; Yu, L.; Xu, B. V 22 T cell subsets, defined by PD-1 and TIM-3 expression, present varied cytokine responses in acute myeloid leukemia patients. Int. Immunopharmacol. 2020, 80, 106122. [CrossRef]

190. Dondero, A.; Pastorino, F.; Della Chiesa, M.; Corrias, M.V.; Morandi, F.; Pistoia, V.; Olive, D.; Bellora, F.; Locatelli, F.; Castellano, A.; et al. PD-L1 expression in metastatic neuroblastoma as an additional mechanism for limiting immune surveillance. Oncoimmunology 2016, 5, e1064578. [CrossRef]

191. Tanaka, Y. Cancer immunotherapy harnessing $\gamma \delta$ T cells and programmed death-1. Immunol. Rev. 2020, 298, 237-253. [CrossRef] [PubMed]

192. He, Y.; Yu, H.; Rozeboom, L.; Rivard, C.J.; Ellison, K.; Dziadziuszko, R.; Suda, K.; Ren, S.; Wu, C.; Hou, L.; et al. LAG-3 Protein Expression in Non-Small Cell Lung Cancer and Its Relationship with PD-1/PD-L1 and Tumor-Infiltrating Lymphocytes. J. Thorac. Oncol. 2017, 12, 814-823. [CrossRef]

193. Alsaab, H.O.; Sau, S.; Alzhrani, R.; Tatiparti, K.; Bhise, K.; Kashaw, S.K.; Iyer, A.K. PD-1 and PD-L1 Checkpoint Signaling Inhibition for Cancer Immunotherapy: Mechanism, Combinations, and Clinical Outcome. Front. Pharmacol. 2017, 8, 561. [CrossRef]

194. Bhat, S.A.; Vedpathak, D.M.; Chiplunkar, S.V. Checkpoint Blockade Rescues the Repressive Effect of Histone Deacetylases Inhibitors on $\gamma \delta$ T Cell Function. Front. Immunol. 2018, 9, 1615. [CrossRef]

195. Catafal-Tardos, E.; Baglioni, M.V.; Bekiaris, V. Inhibiting the Unconventionals: Importance of Immune Checkpoint Receptors in $\gamma \delta$ T, MAIT, and NKT Cells. Cancers 2021, 13, 4647. [CrossRef]

196. Pardoll, D.M. The blockade of immune checkpoints in cancer immunotherapy. Nat. Rev. Cancer 2012, 12, 252-264. [CrossRef]

197. Flippot, R.; Escudier, B.; Albiges, L. Immune Checkpoint Inhibitors: Toward New Paradigms in Renal Cell Carcinoma. Drugs 2018, 78, 1443-1457. [CrossRef] [PubMed]

198. Iwasaki, M.; Tanaka, Y.; Kobayashi, H.; Murata-Hirai, K.; Miyabe, H.; Sugie, T.; Toi, M.; Minato, N. Expression and function of PD-1 in human $\gamma \delta$ T cells that recognize phosphoantigens. Eur. J. Immunol. 2011, 41, 345-355. [CrossRef]

199. Hoeres, T.; Holzmann, E.; Smetak, M.; Birkmann, J.; Wilhelm, M. PD-1 signaling modulates interferon- $\gamma$ production by Gamma Delta $(\gamma \delta)$ T-Cells in response to leukemia. Oncoimmunology 2019, 8, 1550618. [CrossRef] [PubMed]

200. Munn, D.H.; Mellor, A.L. Indoleamine 2,3 dioxygenase and metabolic control of immune responses. Trends Immunol. 2013, 34, 137-143. [CrossRef] [PubMed]

201. Jonescheit, H.; Oberg, H.-H.; Gonnermann, D.; Hermes, M.; Sulaj, V.; Peters, C.; Kabelitz, D.; Wesch, D. Influence of Indoleamine2,3-Dioxygenase and Its Metabolite Kynurenine on $\gamma \delta$ T Cell Cytotoxicity against Ductal Pancreatic Adenocarcinoma Cells. Cells 2020, 9, 1140. [CrossRef] [PubMed]

202. Li, P.; Wu, R.; Li, K.; Yuan, W.; Zeng, C.; Zhang, Y.; Wang, X.; Zhu, X.; Zhou, J.; Li, P.; et al. IDO Inhibition Facilitates Antitumor Immunity of V $\gamma 9 \mathrm{~V} \delta 2 \mathrm{~T}$ Cells in Triple-Negative Breast Cancer. Front. Oncol. 2021, 11, 679517. [CrossRef] 
203. Nanda, R.; Chow, L.Q.; Dees, E.C.; Berger, R.; Gupta, S.; Geva, R.; Pusztai, L.; Pathiraja, K.; Aktan, G.; Cheng, J.D.; et al. Pembrolizumab in Patients with Advanced Triple-Negative Breast Cancer: Phase Ib KEYNOTE-012 Study. J. Clin. Oncol. 2016, 34, 2460-2467. [CrossRef]

204. Le Naour, J.; Galluzzi, L.; Zitvogel, L.; Kroemer, G.; Vacchelli, E. Trial watch: IDO inhibitors in cancer therapy. Oncoimmunology 2020, 9, 1777625. [CrossRef] [PubMed]

205. Sabbione, F.; Gabelloni, M.L.; Ernst, G.; Gori, M.S.; Salamone, G.; Oleastro, M.; Trevani, A.; Geffner, J.; Jancic, C.C. Neutrophils suppress $\gamma \delta$ T-cell function. Eur. J. Immunol. 2014, 44, 819-830. [CrossRef]

206. Kalyan, S.; Chandrasekaran, V.; Quabius, E.S.; Lindhorst, T.K.; Kabelitz, D. Neutrophil uptake of nitrogen-bisphosphonates leads to the suppression of human peripheral blood $\gamma \delta$ T cells. Cell Mol. Life Sci. 2014, 71, 2335-2346. [CrossRef] [PubMed]

207. Mensurado, S.; Rei, M.; Lança, T.; Ioannou, M.; Gonçalves-Sousa, N.; Kubo, H.; Malissen, M.; Papayannopoulos, V.; Serre, K.; Silva-Santos, B. Tumor-associated neutrophils suppress pro-tumoral IL-17+ $\gamma \delta \mathrm{T}$ cells through induction of oxidative stress. PLoS Biol. 2018, 16, e2004990. [CrossRef] [PubMed]

208. Yi, Y.; He, H.W.; Wang, J.X.; Cai, X.Y.; Li, Y.W.; Zhou, J.; Cheng, Y.F.; Jin, J.J.; Fan, J.; Qiu, S.J. The functional impairment of HCC-infiltrating $\gamma \delta \mathrm{T}$ cells, partially mediated by regulatory T cells in a TGF $\beta$ - and IL-10-dependent manner. J. Hepatol. 2013, 58, 977-983. [CrossRef] [PubMed]

209. Cheng, M.; Qian, L.; Shen, G.; Bian, G.; Xu, T.; Xu, W.; Shen, G.; Hu, S. Microbiota modulate tumoral immune surveillance in lung through a $\gamma \delta \mathrm{T} 17$ immune cell-dependent mechanism. Cancer Res. 2014, 74, 4030-4041. [CrossRef]

210. Pro, B.; Allen, P.; Behdad, A. Hepatosplenic T-cell lymphoma: A rare but challenging entity. Blood 2020, 136, 2018-2026. [CrossRef] [PubMed]

211. Yabe, M.; Miranda, R.N.; Medeiros, L.J. Hepatosplenic T-cell Lymphoma: A review of clinicopathologic features, pathogenesis, and prognostic factors. Hum. Pathol. 2018, 74, 5-16. [CrossRef]

212. Matutes, E. The 2017 WHO update on mature T- and natural killer (NK) cell neoplasms. Int. J. Lab. Hematol. 2018, 40, 97-103. [CrossRef] [PubMed]

213. Macon, W.R.; Levy, N.B.; Kurtin, P.J.; Salhany, K.E.; Elkhalifa, M.Y.; Casey, T.T.; Craig, F.E.; Vnencak-Jones, C.L.; Gulley, M.L.; Park, J.P.; et al. Hepatosplenic alphabeta T-cell lymphomas: A report of 14 cases and comparison with hepatosplenic gammadelta T-cell lymphomas. Am. J. Surg. Pathol. 2001, 25, 285-296. [CrossRef]

214. Foss, F.M.; Horwitz, S.M.; Civallero, M.; Bellei, M.; Marcheselli, L.; Kim, W.S.; Cabrera, M.E.; Dlouhy, I.; Nagler, A.; Advani, R.H.; et al. Incidence and outcomes of rare T cell lymphomas from the T Cell Project: Hepatosplenic, enteropathy associated and peripheral gamma delta T cell lymphomas. Am. J. Hematol. 2020, 95, 151-155. [CrossRef] [PubMed]

215. McKinney, M.; Moffitt, A.B.; Gaulard, P.; Travert, M.; De Leval, L.; Nicolae, A.; Raffeld, M.; Jaffe, E.S.; Pittaluga, S.; Xi, L.; et al. The Genetic Basis of Hepatosplenic T-cell Lymphoma. Cancer Discov. 2017, 7, 369-379. [CrossRef]

216. Swerdlow, S.H.; Campo, E.; Pileri, S.A.; Harris, N.L.; Stein, H.; Siebert, R.; Advani, R.; Ghielmini, M.; Salles, G.A.; Zelenetz, A.D.; et al. The 2016 revision of the World Health Organization classification of lymphoid neoplasms. Blood 2016, 127, 2375-2390. [CrossRef]

217. Guitart, J.; Weisenburger, D.D.; Subtil, A.; Kim, E.; Wood, G.; Duvic, M.; Olsen, E.; Junkins-Hopkins, J.; Rosen, S.; Sundram, U.; et al. Cutaneous $\gamma \delta$ T-cell lymphomas: A spectrum of presentations with overlap with other cytotoxic lymphomas. Am. J. Surg. Pathol. 2012, 36, 1656-1665. [CrossRef]

218. Toro, J.R.; Liewehr, D.J.; Pabby, N.; Sorbara, L.; Raffeld, M.; Steinberg, S.M.; Jaffe, E.S. Gamma-delta T-cell phenotype is associated with significantly decreased survival in cutaneous T-cell lymphoma. Blood 2003, 101, 3407-3412. [CrossRef]

219. Al Somali, Z.; Hamadani, M.; Kharfan-Dabaja, M.; Sureda, A.; El Fakih, R.; Aljurf, M. Enteropathy-Associated T cell Lymphoma. Curr Hematol. Malig. Rep. 2021, 16, 140-147. [CrossRef]

220. van Vliet, C.; Spagnolo, D.V. T- and NK-cell lymphoproliferative disorders of the gastrointestinal tract: Review and update. Pathology 2020, 52, 128-141. [CrossRef]

221. van Wanrooij, R.L.; de Jong, D.; Langerak, A.W.; Ylstra, B.; van Essen, H.F.; Heideman, D.A.; Bontkes, H.J.; Mulder, C.J.; Bouma, G. Novel variant of EATL evolving from mucosal $\gamma \delta$-T-cells in a patient with type I RCD. BMJ Open Gastroenterol. 2015, 2, e000026. [CrossRef] [PubMed]

222. Nicolae, A.; Xi, L.; Pham, T.H.; Pham, T.A.; Navarro, W.; Meeker, H.G.; Pittaluga, S.; Jaffe, E.S.; Raffeld, M. Mutations in the JAK/STAT and RAS signaling pathways are common in intestinal T-cell lymphomas. Leukemia 2016, 30, 2245-2247. [CrossRef] [PubMed]

223. Tse, E.; Gill, H.; Loong, F.; Kim, S.J.; Ng, S.B.; Tang, T.; Ko, Y.H.; Chng, W.J.; Lim, S.T.; Kim, W.S.; et al. Type II enteropathyassociated T-cell lymphoma: A multicenter analysis from the Asia Lymphoma Study Group. Am. J. Hematol. 2012, 87, 663-668. [CrossRef] [PubMed]

224. Tan, S.Y.; Chuang, S.S.; Tang, T.; Tan, L.; Ko, Y.H.; Chuah, K.L.; Ng, S.B.; Chng, W.J.; Gatter, K.; Loong, F.; et al. Type II EATL (epitheliotropic intestinal T-cell lymphoma): A neoplasm of intra-epithelial T-cells with predominant CD8 $\alpha \alpha$ phenotype. Leukemia 2013, 27, 1688-1696. [CrossRef] [PubMed]

225. Chan, J.K.; Chan, A.C.; Cheuk, W.; Wan, S.K.; Lee, W.K.; Lui, Y.H.; Chan, W.K. Type II enteropathy-associated T-cell lymphoma: A distinct aggressive lymphoma with frequent $\gamma \delta$ T-cell receptor expression. Am. J. Surg. Pathol. 2011, 35, 1557-1569. [CrossRef] [PubMed] 
226. Sieniawski, M.; Angamuthu, N.; Boyd, K.; Chasty, R.; Davies, J.; Forsyth, P.; Jack, F.; Lyons, S.; Mounter, P.; Revell, P.; et al. Evaluation of enteropathy-associated T-cell lymphoma comparing standard therapies with a novel regimen including autologous stem cell transplantation. Blood 2010, 115, 3664-3670. [CrossRef]

227. Delabie, J.; Holte, H.; Vose, J.M.; Ullrich, F.; Jaffe, E.S.; Savage, K.J.; Connors, J.M.; Rimsza, L.; Harris, N.L.; Müller-Hermelink, K.; et al. Enteropathy-associated T-cell lymphoma: Clinical and histological findings from the international peripheral T-cell lymphoma project. Blood 2011, 118, 148-155. [CrossRef] [PubMed]

228. Verbeek, W.H.; Van De Water, J.M.; Al-Toma, A.; Oudejans, J.J.; Mulder, C.J.; Coupé, V.M. Incidence of enteropathy-associated T-cell lymphoma: A nation-wide study of a population-based registry in The Netherlands. Scand. J. Gastroenterol. 2008, 43, 1322-1328. [CrossRef]

229. Yi, J.H.; Lee, G.W.; Do, Y.R.; Jung, H.R.; Hong, J.Y.; Yoon, D.H.; Suh, C.; Choi, Y.S.; Yi, S.Y.; Sohn, B.S.; et al. Multicenter retrospective analysis of the clinicopathologic features of monomorphic epitheliotropic intestinal T-cell lymphoma. Ann. Hematol. 2019, 98, 2541-2550. [CrossRef] [PubMed]

230. Malamut, G.; Chandesris, O.; Verkarre, V.; Meresse, B.; Callens, C.; Macintyre, E.; Bouhnik, Y.; Gornet, J.M.; Allez, M.; Jian, R.; et al. Enteropathy associated T cell lymphoma in celiac disease: A large retrospective study. Dig. Liver. Dis. 2013, 45, 377-384. [CrossRef] [PubMed]

231. Cheon, H.; Dziewulska, K.H.; Moosic, K.B.; Olson, K.C.; Gru, A.A.; Feith, D.J.; Loughran, T.P. Advances in the Diagnosis and Treatment of Large Granular Lymphocytic Leukemia. Curr. Hematol. Malig. Rep. 2020, 15, 103-112. [CrossRef] [PubMed]

232. Sandberg, Y.; Almeida, J.; Gonzalez, M.; Lima, M.; Bárcena, P.; Szczepañski, T.; van Gastel-Mol, E.J.; Wind, H.; Balanzategui, A.; van Dongen, J.J.; et al. TCRgammadelta + large granular lymphocyte leukemias reflect the spectrum of normal antigen-selected TCRgammadelta+ T-cells. Leukemia 2006, 20, 505-513. [CrossRef] [PubMed]

233. Bourgault-Rouxel, A.S.; Loughran, T.P., Jr.; Zambello, R.; Epling-Burnette, P.K.; Semenzato, G.; Donadieu, J.; Amiot, L.; Fest, T.; Lamy, T. Clinical spectrum of gammadelta+ T cell LGL leukemia: Analysis of 20 cases. Leuk. Res. 2008, 32, 45-48. [CrossRef] [PubMed]

234. Yabe, M.; Medeiros, L.J.; Wang, S.A.; Konoplev, S.; Ok, C.Y.; Loghavi, S.; Lu, G.; Flores, L.; Khoury, J.D.; Cason, R.C.; et al. Clinicopathologic, Immunophenotypic, Cytogenetic, and Molecular Features of $\gamma \delta$ T-Cell Large Granular Lymphocytic Leukemia: An Analysis of 14 Patients Suggests Biologic Differences With $\alpha \beta$ T-Cell Large Granular Lymphocytic Leukemia. Am. J. Clin. Pathol. 2015, 144, 607-619. [CrossRef]

235. Barilà, G.; Teramo, A.; Calabretto, G.; Vicenzetto, C.; Gasparini, V.R.; Pavan, L.; Leoncin, M.; Vedovato, S.; Frigo, A.C.; Facco, M.; et al. Stat 3 mutations impact on overall survival in large granular lymphocyte leukemia: A single-center experience of 205 patients. Leukemia 2020, 34, 1116-1124. [CrossRef] [PubMed]

236. Matos, D.M.; Rizzatti, E.G.; Fernandes, M.; Buccheri, V.; Falcão, R.P. Gammadelta and alphabeta T-cell acute lymphoblastic leukemia: Comparison of their clinical and immunophenotypic features. Haematologica 2005, 90, $264-266$.

237. Pui, C.H.; Pei, D.; Cheng, C.; Tomchuck, S.L.; Evans, S.N.; Inaba, H.; Jeha, S.; Raimondi, S.C.; Choi, J.K.; Thomas, P.G.; et al. Treatment response and outcome of children with T-cell acute lymphoblastic leukemia expressing the gamma-delta T-cell receptor. Oncoimmunology 2019, 8, 1599637. [CrossRef]

238. Herling, M.; Rengstl, B.; Scholtysik, R.; Hartmann, S.; Küppers, R.; Hansmann, M.-L.; Diebner, H.H.; Roeder, I.; Abken, H.; Newrzela, S.; et al. Concepts in mature T-cell lymphomas-Highlights from an international joint symposium on T-cell immunology and oncology. Leuk. Lymphoma 2017, 58, 788-796. [CrossRef] [PubMed]

239. Gowda, L.; Foss, F. Hepatosplenic T-Cell Lymphomas. Cancer Treat. Res. 2019, 176, 185-193. [CrossRef]

240. Yabe, M.; Medeiros, L.J.; Daneshbod, Y.; Davanlou, M.; Bueso-Ramos, C.E.; Moran, E.J.; Young, K.H.; Miranda, R.N. Hepatosplenic T-cell lymphoma arising in patients with immunodysregulatory disorders: A study of 7 patients who did not receive tumor necrosis factor- $\alpha$ inhibitor therapy and literature review. Ann. Diagn. Pathol. 2017, 26, 16-22. [CrossRef] [PubMed]

241. Kotlyar, D.S.; Osterman, M.T.; Diamond, R.H.; Porter, D.; Blonski, W.C.; Wasik, M.; Sampat, S.; Mendizabal, M.; Lin, M.V.; Lichtenstein, G.R. A systematic review of factors that contribute to hepatosplenic T-cell lymphoma in patients with inflammatory bowel disease. Clin. Gastroenterol. Hepatol. 2011, 9, 36-41.e1. [CrossRef] [PubMed]

242. Lamy, T.; Moignet, A.; Loughran, T.P. LGL leukemia: From pathogenesis to treatment. Blood 2017, 129, 1082-1094. [CrossRef] [PubMed]

243. Savola, P.; Kelkka, T.; Rajala, H.L.; Kuuliala, A.; Kuuliala, K.; Eldfors, S.; Ellonen, P.; Lagström, S.; Lepistö, M.; Hannunen, T.; et al. Somatic mutations in clonally expanded cytotoxic T lymphocytes in patients with newly diagnosed rheumatoid arthritis. Nat. Commun. 2017, 8, 15869. [CrossRef]

244. Koskela, H.L.; Eldfors, S.; Ellonen, P.; van Adrichem, A.J.; Kuusanmäki, H.; Andersson, E.I.; Lagström, S.; Clemente, M.J.; Olson, T.; Jalkanen, S.E.; et al. Somatic STAT3 mutations in large granular lymphocytic leukemia. N. Engl. J. Med. 2012, 366, 1905-1913. [CrossRef] [PubMed]

245. Su, D.; Shen, M.; Li, X.; Sun, L. Roles of $\gamma \delta$ T cells in the pathogenesis of autoimmune diseases. Clin. Dev. Immunol. 2013, $2013,985753$. [CrossRef]

246. Langerak, A.W.; Wolvers-Tettero, I.L.; van den Beemd, M.W.; van Wering, E.R.; Ludwig, W.D.; Hählen, K.; Necker, A.; van Dongen, J.J. Immunophenotypic and immunogenotypic characteristics of TCRgammadelta+ T cell acute lymphoblastic leukemia. Leukemia 1999, 13, 206-214. [CrossRef] [PubMed] 
247. Falini, B.; Flenghi, L.; Pileri, S.; Pelicci, P.; Fagioli, M.; Martelli, M.F.; Moretta, L.; Ciccone, E. Distribution of T cells bearing different forms of the $\mathrm{T}$ cell receptor gamma/delta in normal and pathological human tissues. J. Immunol. 1989, 143, $2480-2488$. [PubMed]

248. Casorati, G.; De Libero, G.; Lanzavecchia, A.; Migone, N. Molecular analysis of human gamma/delta + clones from thymus and peripheral blood. J. Exp. Med. 1989, 170, 1521-1535. [CrossRef] [PubMed]

249. Wilson, A.L.; Swerdlow, S.H.; Przybylski, G.K.; Surti, U.; Choi, J.K.; Campo, E.; Trucco, M.M.; Van Oss, S.B.; Felgar, R.E. Intestinal $\gamma \delta$ T-cell lymphomas are most frequently of type II enteropathy-associated T-cell type. Hum. Pathol. 2013, 44, 1131-1145. [CrossRef]

250. Przybylski, G.K.; Wu, H.; Macon, W.R.; Finan, J.; Leonard, D.G.; Felgar, R.E.; DiGiuseppe, J.A.; Nowell, P.C.; Swerdlow, S.H.; Kadin, M.E.; et al. Hepatosplenic and subcutaneous panniculitis-like gamma/delta T cell lymphomas are derived from different Vdelta subsets of gamma/delta T lymphocytes. J. Mol. Diagn. 2000, 2, 11-19. [CrossRef]

251. Daniels, J.; Doukas, P.G.; Escala, M.E.M.; Ringbloom, K.G.; Shih, D.J.H.; Yang, J.; Tegtmeyer, K.; Park, J.; Thomas, J.J.; Selli, M.E.; et al. Cellular origins and genetic landscape of cutaneous gamma delta T cell lymphomas. Nat. Commun. 2020, 11, 1806. [CrossRef] [PubMed]

252. Arnulf, B.; Copie-Bergman, C.; Delfau-Larue, M.H.; Lavergne-Slove, A.; Bosq, J.; Wechsler, J.; Wassef, M.; Matuchansky, C.; Epardeau, B.; Stern, M.; et al. Nonhepatosplenic gammadelta T-cell lymphoma: A subset of cytotoxic lymphomas with mucosal or skin localization. Blood 1998, 91, 1723-1731. [PubMed]

253. Belhadj, K.; Reyes, F.; Farcet, J.P.; Tilly, H.; Bastard, C.; Angonin, R.; Deconinck, E.; Charlotte, F.; Leblond, V.; Labouyrie, E.; et al. Hepatosplenic gammadelta T-cell lymphoma is a rare clinicopathologic entity with poor outcome: Report on a series of 21 patients. Blood 2003, 102, 4261-4269. [CrossRef]

254. Finalet Ferreiro, J.; Rouhigharabaei, L.; Urbankova, H.; van der Krogt, J.A.; Michaux, L.; Shetty, S.; Krenacs, L.; Tousseyn, T.; De Paepe, P.; Uyttebroeck, A.; et al. Integrative genomic and transcriptomic analysis identified candidate genes implicated in the pathogenesis of hepatosplenic T-cell lymphoma. PLoS ONE 2014, 9, e102977. [CrossRef]

255. Roberti, A.; Dobay, M.P.; Bisig, B.; Vallois, D.; Boéchat, C.; Lanitis, E.; Bouchindhomme, B.; Parrens, M.C.; Bossard, C.; QuintanillaMartinez, L.; et al. Type II enteropathy-associated T-cell lymphoma features a unique genomic profile with highly recurrent SETD2 alterations. Nat. Commun. 2016, 7, 12602. [CrossRef]

256. Ben Abdelali, R.; Roggy, A.; Leguay, T.; Cieslak, A.; Renneville, A.; Touzart, A.; Banos, A.; Randriamalala, E.; Caillot, D.; Lioure, B.; et al. SET-NUP214 is a recurrent $\gamma \delta$ lineage-specific fusion transcript associated with corticosteroid/chemotherapy resistance in adult T-ALL. Blood 2014, 123, 1860-1863. [CrossRef]

257. Asnafi, V.; Radford-Weiss, I.; Dastugue, N.; Bayle, C.; Leboeuf, D.; Charrin, C.; Garand, R.; Lafage-Pochitaloff, M.; Delabesse, E.; Buzyn, A.; et al. CALM-AF10 is a common fusion transcript in T-ALL and is specific to the TCRgammadelta lineage. Blood 2003, 102, 1000-1006. [CrossRef] [PubMed]

258. Schrader, A.; Crispatzu, G.; Oberbeck, S.; Mayer, P.; Pützer, S.; von Jan, J.; Vasyutina, E.; Warner, K.; Weit, N.; Pflug, N.; et al. Actionable perturbations of damage responses by TCL1/ATM and epigenetic lesions form the basis of T-PLL. Nat. Commun. 2018, 9, 697. [CrossRef]

259. Chiarle, R.; Voena, C.; Ambrogio, C.; Piva, R.; Inghirami, G. The anaplastic lymphoma kinase in the pathogenesis of cancer. Nat. Rev. Cancer 2008, 8, 11-23. [CrossRef]

260. Muro, R.; Takayanagi, H.; Nitta, T. T cell receptor signaling for $\gamma \delta$ T cell development. Inflamm Regen 2019, 39, 6. [CrossRef]

261. Fiala, G.J.; Gomes, A.Q.; Silva-Santos, B. From thymus to periphery: Molecular basis of effector $\gamma \delta$-T cell differentiation. Immunol. Rev. 2020, 298, 47-60. [CrossRef] [PubMed]

262. Hoelbl, A.; Kovacic, B.; Kerenyi, M.A.; Simma, O.; Warsch, W.; Cui, Y.; Beug, H.; Hennighausen, L.; Moriggl, R.; Sexl, V. Clarifying the role of Stat5 in lymphoid development and Abelson-induced transformation. Blood 2006, 107, 4898-4906. [CrossRef]

263. Orlova, A.; Wingelhofer, B.; Neubauer, H.A.; Maurer, B.; Berger-Becvar, A.; Keserú, G.M.; Gunning, P.T.; Valent, P.; Moriggl, R. Emerging therapeutic targets in myeloproliferative neoplasms and peripheral T-cell leukemia and lymphomas. Expert Opin. Ther. Targets 2018, 22, 45-57. [CrossRef] [PubMed]

264. Wingelhofer, B.; Neubauer, H.A.; Valent, P.; Han, X.; Constantinescu, S.N.; Gunning, P.T.; Müller, M.; Moriggl, R. Implications of STAT3 and STAT5 signaling on gene regulation and chromatin remodeling in hematopoietic cancer. Leukemia 2018, 32, 1713-1726. [CrossRef] [PubMed]

265. Brachet-Botineau, M.; Polomski, M.; Neubauer, H.A.; Juen, L.; Hédou, D.; Viaud-Massuard, M.-C.; Prié, G.; Gouilleux, F. Pharmacological Inhibition of Oncogenic STAT3 and STAT5 Signaling in Hematopoietic Cancers. Cancers 2020, 12, 240. [CrossRef] [PubMed]

266. Pham, H.T.T.; Maurer, B.; Prchal-Murphy, M.; Grausenburger, R.; Grundschober, E.; Javaheri, T.; Nivarthi, H.; Boersma, A.; Kolbe, T.; Elabd, M.; et al. STAT5BN642H is a driver mutation for T cell neoplasia. J. Clin. Investig. 2018, 128, 387-401. [CrossRef] [PubMed]

267. de Araujo, E.D.; Erdogan, F.; Neubauer, H.A.; Meneksedag-Erol, D.; Manaswiyoungkul, P.; Eram, M.S.; Seo, H.S.; Qadree, A.K.; Israelian, J.; Orlova, A.; et al. Structural and functional consequences of the STAT5B. Nat. Commun. 2019, 10, 2517. [CrossRef]

268. Nicolae, A.; Xi, L.; Pittaluga, S.; Abdullaev, Z.; Pack, S.D.; Chen, J.; Waldmann, T.A.; Jaffe, E.S.; Raffeld, M. Frequent STAT5B mutations in $\gamma \delta$ hepatosplenic T-cell lymphomas. Leukemia 2014, 28, 2244-2248. [CrossRef] [PubMed] 
269. Moffitt, A.B.; Ondrejka, S.L.; McKinney, M.; Rempel, R.E.; Goodlad, J.R.; Teh, C.H.; Leppa, S.; Mannisto, S.; Kovanen, P.E.; Tse, E.; et al. Enteropathy-associated T cell lymphoma subtypes are characterized by loss of function of SETD2. J. Exp. Med. 2017, 214, 1371-1386. [CrossRef] [PubMed]

270. Ribeiro, S.T.; Tesio, M.; Ribot, J.C.; Macintyre, E.; Barata, J.T.; Silva-Santos, B. Casein kinase 2 controls the survival of normal thymic and leukemic $\gamma \delta \mathrm{T}$ cells via promotion of AKT signaling. Leukemia 2017, 31, 1603-1610. [CrossRef] [PubMed]

271. Kim, R.; Boissel, N.; Touzart, A.; Leguay, T.; Thonier, F.; Thomas, X.; Raffoux, E.; Huguet, F.; Villarese, P.; Fourrage, C.; et al. Adult T-cell acute lymphoblastic leukemias with IL7R pathway mutations are slow-responders who do not benefit from allogeneic stem-cell transplantation. Leukemia 2020, 34, 1730-1740. [CrossRef]

272. Santana, V.M.; Abromowitch, M.; Sandlund, J.T.; Behm, F.G.; Ayers, G.D.; Roberson, P.K.; Pui, C.H. MACOP-B treatment in children and adolescents with advanced diffuse large-cell non-Hodgkin's lymphoma. Leukemia 1993, 7, $187-191$.

273. Zinzani, P.L.; Tura, S.; Cajozzo, A.; Leone, G.; Papa, G.; Gentilini, P.; Rossi, G.; Aitini, E.; Mandelli, F. Anthracycline containing regimens in intermediate grade lymphoma. Italian Cooperative Study Group on Intermediate Grade Malignant Lymphoma. Leuk. Lymphoma 1993, 10, 39-41. [CrossRef]

274. Bezwoda, W.R.; Rastogi, R.B. A randomized comparative study of cyclophosphamide, vincristine, doxorubicin, and prednisolone and cyclophosphamide, vincristine, mitoxantrone, and prednisolone regimens in the treatment of intermediate- and high-grade lymphoma with 8 years' follow-up. Semin. Hematol. 1994, 31, 3. [PubMed]

275. Köppler, H.; Pflüger, K.H.; Eschenbach, I.; Pfab, R.; Birkmann, J.; Zeller, W.; Holle, R.; Steinhauer, U.E.; Gropp, C.; Oehl, S.; et al. Randomised comparison of CHOEP versus alternating hCHOP/IVEP for high-grade non-Hodgkin's lymphomas: Treatment results and prognostic factor analysis in a multi-centre trial. Ann. Oncol. 1994, 5, 49-55. [CrossRef]

276. Kesavan, M.; Eyre, T.A.; Collins, G.P. Front-Line Treatment of High Grade B Cell Non-Hodgkin Lymphoma. Curr. Hematol. Malig. Rep. 2019, 14, 207-218. [CrossRef]

277. Schmitz, N.; Nickelsen, M.; Ziepert, M.; Haenel, M.; Borchmann, P.; Schmidt, C.; Viardot, A.; Bentz, M.; Peter, N.; Ehninger, G.; et al. Conventional chemotherapy (CHOEP-14) with rituximab or high-dose chemotherapy (MegaCHOEP) with rituximab for young, high-risk patients with aggressive B-cell lymphoma: An open-label, randomised, phase 3 trial (DSHNHL 2002-1). Lancet Oncol. 2012, 13, 1250-1259. [CrossRef]

278. Cunningham, D.; Hawkes, E.A.; Jack, A.; Qian, W.; Smith, P.; Mouncey, P.; Pocock, C.; Ardeshna, K.M.; Radford, J.A.; McMillan, A.; et al. Rituximab plus cyclophosphamide, doxorubicin, vincristine, and prednisolone in patients with newly diagnosed diffuse large B-cell non-Hodgkin lymphoma: A phase 3 comparison of dose intensification with 14-day versus 21-day cycles. Lancet 2013, 381, 1817-1826. [CrossRef]

279. Molina, T.J.; Canioni, D.; Copie-Bergman, C.; Recher, C.; Brière, J.; Haioun, C.; Berger, F.; Fermé, C.; Copin, M.C.; Casasnovas, O.; et al. Young patients with non-germinal center B-cell-like diffuse large B-cell lymphoma benefit from intensified chemotherapy with ACVBP plus rituximab compared with CHOP plus rituximab: Analysis of data from the Groupe d'Etudes des Lymphomes de l'Adulte/lymphoma study association phase III trial LNH 03-2B. J. Clin. Oncol. 2014, 32, 3996-4003. [CrossRef] [PubMed]

280. Dinçol, D.; Akbulut, H.; Içli, F.; Samur, M.; Karaoğuz, H.; Demirkazik, A.; Cay, F. Results of the cyclophosphamide, doxorubicin, vincristine, prednisolone $(\mathrm{CHOP})+/$ - bleomycin treatment and evaluation of prognostic factors in aggressive lymphomas in Turkey. Oncology 1997, 54, 376-379. [CrossRef] [PubMed]

281. Niitsu, N.; Okamoto, M.; Kuraishi, Y.; Nakamura, S.; Kodama, F.; Hirano, M. CyclOBEAP (cyclophosphamide, vincristine, bleomycin, etoposide, doxorubicin, prednisolone) regimen with granulocyte colony-stimulating factor (G-CSF) for patients with aggressive non-Hodgkin's lymphoma: A pilot study. The Adult Lymphoma Treatment Study Group (ALTSG). Eur. J. Haematol. 2000, 65, 188-194. [CrossRef]

282. Meerwaldt, J.H.; Carde, P.; Somers, R.; Thomas, J.; Kluin-Nelemans, J.C.; Bron, D.; Noordijk, E.M.; Cosset, J.M.; Bijnens, L.; Teodorovic, I.; et al. Persistent improved results after adding vincristine and bleomycin to a cyclophosphamide/hydroxorubicin/Vm26/prednisone combination (CHVmP) in stage III-IV intermediate- and high-grade non-Hodgkin's lymphoma. The EORTC Lymphoma Cooperative Group. Ann. Oncol. 1997, 8, 67-70. [CrossRef] [PubMed]

283. Wilder, D.D.; Ogden, J.L.; Jain, V.K. Efficacy of fludarabine/mitoxantrone/dexamethasone alternating with CHOP in bulky follicular non-Hodgkin's lymphoma. Clin. Lymphoma 2002, 2, 229-237. [CrossRef] [PubMed]

284. Sakai, R.; Fujisawa, S.; Fujimaki, K.; Kanamori, H.; Ishigatsubo, Y. Long-term remission in a patient with hepatosplenic gammadelta $\mathrm{T}$ cell lymphoma after cord blood stem cell transplantation following autologous peripheral blood stem cell transplantation. Bone Marrow Transplant. 2006, 37, 537-538. [CrossRef] [PubMed]

285. Gassas, A.; Kirby, M.; Weitzman, S.; Ngan, B.; Abla, O.; Doyle, J.J. Hepatosplenic gammadelta T-cell lymphoma in a 10-year-old boy successfully treated with hematopoietic stem cell transplantation. Am. J. Hematol. 2004, 75, 113-114. [CrossRef] [PubMed]

286. Wang, Q.; Jiang, Y.; Zhu, Q.; Duan, Y.; Chen, X.; Xu, T.; Jin, Z.; Li, C.; Wu, D.; Huang, H. Clinical features and treatment outcomes of 14 patients with hepatosplenic $\gamma \delta$ T-cell lymphoma. J. Cancer Res. Clin. Oncol. 2021, 147, 3441-3445. [CrossRef] [PubMed]

287. Carlo-Stella, C.; Delarue, R.; Scarfo, L.; Barde, P.J.; Nair, A.; Locatelli, S.L.; Morello, L.; Magagnoli, M.; Vakkalanka, S.; Viswanadha, S.; et al. A First-in-human Study of Tenalisib (RP6530), a Dual PI3K $\delta / \gamma$ Inhibitor, in Patients with Relapsed/Refractory Hematologic Malignancies: Results from the European Study. Clin. Lymphoma Myeloma. Leuk. 2020, 20, 78-86. [CrossRef] [PubMed]

288. Laribi, K.; Alani, M.; Truong, C.; Baugier de Materre, A. Recent Advances in the Treatment of Peripheral T-Cell Lymphoma. Oncologist 2018, 23, 1039-1053. [CrossRef] [PubMed] 
289. Wang, X.T.; Guo, W.; Sun, M.; Han, W.; Du, Z.H.; Wang, X.X.; Du, B.B.; Bai, O. Effect of chidamide on treating hepatosplenic T-cell lymphoma: A case report. World J. Clin. Cases 2020, 8, 3122-3129. [CrossRef] [PubMed]

290. Aldinucci, D.; Poletto, D.; Zagonel, V.; Rupolo, M.; Degan, M.; Nanni, P.; Gattei, V.; Pinto, A. In vitro and in vivo effects of 2'-deoxycoformycin (Pentostatin) on tumour cells from human gammadelta+ T-cell malignancies. Br. J. Haematol. 2000, 110, 188-196. [CrossRef] [PubMed]

291. Grigg, A.P. 2'-Deoxycoformycin for hepatosplenic gammadelta T-cell lymphoma. Leuk. Lymphoma 2001, 42, 797-799. [CrossRef] [PubMed]

292. Iannitto, E.; Barbera, V.; Quintini, G.; Cirrincione, S.; Leone, M. Hepatosplenic gammadelta T-cell lymphoma: Complete response induced by treatment with pentostatin. Br. J. Haematol. 2002, 117, 995-996. [CrossRef] [PubMed]

293. Bennett, M.; Matutes, E.; Gaulard, P. Hepatosplenic T cell lymphoma responsive to 2'-deoxycoformycin therapy. Am. J. Hematol. 2010, 85, 727-729. [CrossRef] [PubMed]

294. Bergmann, A.K.; Fataccioli, V.; Castellano, G.; Martin-Garcia, N.; Pelletier, L.; Ammerpohl, O.; Bergmann, J.; Bhat, J.; Pau, E.C.S.; Martín-Subero, J.I.; et al. DNA methylation profiling of hepatosplenic T-cell lymphoma. Haematologica 2019, 104, e104-e107. [CrossRef] [PubMed] 